\title{
Monitoring and corporate disclosure: Evidence from a natural experiment
}

\author{
Rustom M. Irani ${ }^{\mathrm{a}, *}$, David Oesch ${ }^{\mathrm{b}}$ \\ a College of Business, University of Illinois at Urbana-Champaign, 444 Wohlers Hall, 1206 South Sixth Street, Champaign, IL 61820, USA \\ ${ }^{\mathrm{b}}$ Swiss Institute of Banking and Finance, University of St. Gallen, Rosenbergstrasse 52, CH-9000, St. Gallen, Switzerland
}

\section{A R T I C L E I N F O}

\section{Article history:}

Received 25 September 2012

Received in revised form

17 December 2012

Accepted 18 January 2013

Available online 1 March 2013

\section{JEL classifications:}

D82

G24

G30

G34

M40

Keywords:

Analyst coverage

Corporate governance

Reporting decisions

\begin{abstract}
A B S T R A C T
Using an experimental design that exploits exogenous reductions in coverage resulting from brokerage house mergers, we find that a reduction in coverage causes a deterioration in financial reporting quality. The effect of coverage on disclosure is more pronounced for firms with weak shareholder rights, consistent with a substitution effect between analyst monitoring and other corporate governance mechanisms. The effects we uncover using our experimental design are an order of magnitude larger than estimates from ordinary least squares regressions that do not account for the endogeneity of coverage. Overall, our results suggest that security analysts monitor managers and entrenched managers adopt less informative disclosure policies in the absence of such scrutiny.
\end{abstract}

(c) 2013 Elsevier B.V. All rights reserved.

\section{Introduction}

Corporate governance mechanisms that act to mitigate agency costs often require management to disclose information. In addition, information intermediaries undertake private information production that has the potential to inform investors and facilitate the detection and discipline of managerial rent-seeking behavior. The goal of this paper

\footnotetext{
We would like to thank Bill Schwert (the editor) and Patricia Dechow (the referee) for many helpful comments and suggestions. We also thank Viral Acharya, Heitor Almeida, Jeffrey Brown, Francois Derrien, Lily Fang, Vyacheslav Fos, Marcin Kacperczyk, Jonathan Karpoff, Ambrus Kecskes, Adam Kolasinski, Hanh Le, Oliver Randall, and Xuan Tian. We are grateful to Feng Li for sharing data with us.

* Corresponding author.

E-mail addresses: rirani@illinois.edu (R.M. Irani), david.oesch@unisg.ch (D. Oesch).
}

is to understand the potential monitoring role of information intermediaries and how they interact with other corporate governance mechanisms, an important issue given the large direct costs of "cooking the books" (Karpo, Lee, and Martin, 2008a,b) and the potential macroeconomic distortions associated with such managerial misbehavior (Kedia and Philippon, 2009). Our focus is on one key information intermediary, securities analysts, and we examine how analysts influence corporate disclosure.

Any empirical analysis of the relationship between a firm's monitoring mechanisms and disclosure policy is complicated by endogeneity. If a regression uncovers a relationship between a measure of the presence of information intermediaries and a measure of disclosure, it is unclear which way causality runs. A second identification problem - that of omitted variable bias-will confound inference if (unobservable) investment opportunities both attract coverage and influence corporate reporting. 
To overcome these obstacles, we employ a quasiexperimental design that allows us to examine the reaction of firms to a plausibly exogenous decrease in coverage caused by mergers of brokerage houses (originally proposed by Hong and Kacperczyk, 2010). As a result of the merger of two brokerage houses, the new entity might end up with a redundant analyst (due to overlapping coverage) and, consequently, one analyst might be let go. Thus, merger-related factors may lead to a decrease in analyst coverage for the firm(s) being covered by both houses. ${ }^{1}$

Our identification strategy uses 13 brokerage house merger events staggered from 1994 until 2005 and accommodates the universe of publicly traded U.S. firms. Associated with these mergers are 1,179 unique stocks that were covered by both houses in the year prior to the merger, our treatment sample. Employing a difference-in-differences methodology, we compare the changes in financial reporting quality of these treatment firms to a control sample of observationally equivalent firms unaffected by the merger, thus identifying the causal change in financial reporting quality resulting from the loss of coverage.

Using this design, our analysis delivers two main results. First, we provide causal evidence that information intermediaries influence the nature of corporate disclosure. Using discretionary accruals (Dechow, Sloan, and Sweeney, 1995; Jones, 1991) as our primary measure of corporate disclosure, we find that financial reporting quality deteriorates following an exogenous reduction in coverage. Specifically, our estimates imply that a reduction in analyst coverage leads firms to use more discretionary accruals in their financial reporting. We show this treatment effect is nonlinear and more pronounced for firms with low initial coverage, corroborating our identification strategy and providing direct evidence that corporate disclosure responds to large percentage drops in analyst coverage.

Second, we show how monitoring by information intermediaries interacts with traditional governance mechanisms. While analysts and governance mechanisms perform essentially the same function-to scrutinize and discipline value-destroying behavior by managementthey exercise this discipline through different means. On the one hand, monitoring by security analysts may provide discipline independently of traditional corporate governance, thus acting as a substitute. Alternatively, if the information produced and disseminated by analysts improves the efficacy of other governance mechanisms, then these two monitoring devices may complement each other. Our objective is to understand whether analyst monitoring serves as a substitute or complement to internal corporate governance mechanisms. Our tests show that the effect of coverage on disclosure is only present among firms with poor governance, consistent

\footnotetext{
${ }^{1}$ The net impact that the reduction in analyst coverage has on information asymmetry has been documented in the literature. Recent contributions highlight: an increase in the forecast error variance among analysts that continue to cover the stock (Hong and Kacperczyk, 2010); concerning stock market reaction, less price efficiency and liquidity, greater earnings surprises, and increased trading volatility around earnings announcements (Kelly and Ljungqvist, 2007, 2012).
}

with a substitution effect between corporate governance and coverage. We find that a reduction in coverage does not lead to a deterioration in reporting quality among well-governed firms, suggesting that the governance mechanisms in place are sufficient to dissuade managerial opportunism.

We conduct a series of robustness tests to confirm the validity of our empirical results. We limit concerns regarding alternative explanations that our results could be due to systematic differences in industries, mergers, or firms by demonstrating that our estimates are robust to the inclusion of the respective fixed effects. In addition, we show that our estimates are not driven by potential differences between treated and non-treated firms. To this end, we take advantage of our panel regression methodology and include a number of control variables, as well as incorporating a difference-in-differences matching estimator. Our results are robust to employing different measures of financial reporting quality, ranging from non-regression-based measures of accruals to measures that are based on textual analysis of the information provided in annual reports. We also investigate the validity of our natural experiment, specifically, the no pre-existing trends assumption, by conducting "placebo" mergers that shift the event date by one year either in the future or past. We also study the dynamic effects of the mergers and provide evidence that there are no posttrends in the data. Finally, we show that our results are not driven by a single merger or a subset of mergers.

We conclude our empirical analysis with a series of standard OLS regressions of financial reporting quality on analyst coverage that do not correct for the endogeneity of coverage. These estimates suggest that a higher number of analysts is correlated with lower financial reporting quality, in contrast to the directional effect we uncover using our experimental design. However, the effects we document using this alternative specification are economically small and are not robust to the inclusion of firm fixed effects. Moreover, these results are very hard to interpret because analyst coverage is likely to be endogenous. This confirms the usefulness of our empirical approach.

Our findings relate to a large body of theoretical research that has identified a trade-off between monitoring by information intermediaries and corporate disclosure. On the one hand, information intermediaries play an important role as whistle blowers and are often the first to detect managerial misbehavior (Dyck, Morse, and Zingales, 2010). With fewer information intermediaries and less monitors, the threat of action by some claimant may diminish, since it is less likely that managerial misbehavior will be detected. Facing a lower probability of detection and thus a lower expected cost of manipulation, self-interested managers may be more likely to conceal firm performance and pursue rent-seeking behavior (Kedia and Philippon, 2009). ${ }^{2}$

\footnotetext{
${ }^{2}$ For example, Bergstresser and Philippon (2006) provide compelling evidence of management manipulating reported earnings, while selling shares and exercise options at a premium.
} 
On the other hand, fewer information intermediaries may result in greater information asymmetry between insiders and investors and also among investors. Greater information asymmetry between insiders and outsiders could matter if the firm is funded primarily with information-sensitive securities, as in Myers and Majluf (1984). Greater disparity of information among investors could lead to a loss of liquidity (Diamond, 1985; Diamond and Verrecchia, 1991), say, if the less-informed retail investors withdraw from the market (Balakrishnan, Billings, Kelly, and Ljungqvist, 2012; Kelly and Ljungqvist, 2007, 2012). These two distinct channels could both lead to an increased cost of capital and loss of firm value, which could prompt management to increase disclosure.

Consistent with models of managerial misbehavior and earnings manipulation, we find that, on average, a reduction in analyst coverage leads managers to adopt less informative disclosure policies. Moreover, we find this effect to be most pronounced among firms with more anti-takeover provisions in place, that is, among "entrenched" managers. In addition, and consistent with the information asymmetry channel, we find the effect of coverage on disclosure attenuates among the subsample of firms with greater need to access market finance (e.g., equity issuers).

We contribute to the empirical literature on the interaction between corporate governance and monitoring mechanisms and corporate disclosure. Perhaps unsurprisingly, given the inherent identification difficulties, empirical research on this relationship has so far reported mixed results. Lang and Lundholm (1993) and Healy, Hutton, and Palepu (1999), for example, find that firms with greater disclosure quality are covered by more analysts. Notably, Anantharaman and Zhang (2012) show that managers increase the volume of public financial guidance in response to decreases in analyst coverage of their firms. Yu (2008) investigates earnings management and analyst following and finds evidence of a negative relationship. We contribute to this literature by employing an experimental design, allowing us to establish a causal relationship and demonstrate that a reduction in analyst coverage causes a deterioration in financial reporting quality.

Our paper also adds to the growing body of research that uses either brokerage house mergers or closures as exogenous shocks to information asymmetry. This research uses this natural experiment to study security analyst coverage and reporting bias (Hong and Kacperczyk, 2010), credit ratings (Fong, Hong, Kacperczyk, and Kubik, 2012), firm valuation and the cost of equity (Kelly and Ljungqvist, 2007, 2012), cost of debt (Derrien, Kecskes, and Mansi, 2012), real firm performance and corporate policies (Derrien and Kecskes, forthcoming), or innovation (He and Tian, forthcoming). In a related contemporaneous study, Balakrishnan, Billings, Kelly, and Ljungqvist (2012) use this experimental setting to investigate the effect of voluntary corporate disclosure and stock liquidity. They find that by increasing the volume and timeliness of voluntary public disclosure, management mitigates the loss of liquidity associated with the reduction in analyst coverage and loss of public information. Our contribution is to study the role of security analysts as external monitors. We investigate how monitoring by analysts interacts with internal governance mechanisms of the firm and influences the informativeness of corporate disclosure. We show that despite the potential loss of liquidity due to the loss of coverage, managers at firms with weak internal governance mechanisms reduce the quality of financial reporting.

The remainder of this paper is structured as follows. Section 2 describes the data and empirical design. Section 3 reports the results of the empirical analysis. Section 4 concludes.

\section{Empirical setup and data}

\subsection{Identification strategy}

The simplest way to investigate the question of how corporate disclosure differs in the presence of monitoring and information production by outsiders is to regress a measure of financial reporting quality on a measure of information production (e.g., number of analysts) or information asymmetry (e.g., the probability of informed trading of Easley, Kiefer, and O'Hara, 1996). The estimates obtained from such regressions, however, are very difficult to interpret due to the confounding effects of endogeneity. For instance, if a positive correlation between analyst coverage and financial reporting quality were uncovered, this may reflect the decision of analysts to follow firms with more informative financial statements (as in Healy, Hutton, and Palepu, 1999).

To overcome this endogeneity problem, we consider: first, securities analysts as an information intermediary associated with a particular firm; second, a setting where there is an unexpected shock to the number of securities analysts. Specifically, we use the mergers of brokerage houses as a source of exogenous variation in analyst coverage. The underlying assumption is that two merging brokerage houses-both initially covering the same stock-are expected to let one of these analysts go, leading to a reduction in analyst coverage for a given firm. Importantly, the coverage termination is independent of potentially unobservable firm characteristics (e.g., investment opportunities or managerial talent) and was not a decision made by the security analyst.

To identify the relevant mergers, we follow Hong and Kacperczyk (2010). We start by selecting mergers in the Securities Data Company (SDC) Mergers and Acquisitions database involving financial institutions (firms with Standard Industrial Classification (SIC) code 6211, "Investment Commodity Firms, Dealers, and Exchanges”). We retain mergers where there is coverage in Thomson Reuters Institutional Brokers' Estimate System $(\mathrm{I} / \mathrm{B} / \mathrm{E} / \mathrm{S})$ for both the bidder and the target. We require that both merging brokerages have overlapping coverage, i.e., analysts covering at least two of the same stocks. This ensures that the empirical approach is applicable. As a final constraint, the mergers we consider occur post-1988 to ensure that we can compute our measures of financial reporting quality (defined below). These filters leave us with the 13 mergers that are the central focus of this study.

To identify the impact of each of these mergers on stock coverage as well as the career outcomes of analysts 
Table 1

Descriptive statistics for mergers.

This table reports details of the merger events considered in this paper. The details were compiled from I/B/E/S following Hong and Kacperczyk (2010), as described in the text. The names and dates of the merging brokerage houses are included. For each merger, the brokerage house in the top row is the acquiring house and the brokerage house in the bottom row is the target. The table breaks out the number of stocks that were covered by both the merging brokerage houses and the overlap in coverage prior to the merger. These stocks make up our treatment sample and are the focus of this paper. The percentage of overlapping coverage retained is also included. This refers to the percentage of overlapping stocks that continue (i.e., in the year following the merger) to be covered by analysts at the bidder and by (retained) analysts at the target. Career outcomes for the analysts employed at the acquiring and target houses are also provided, including the number and percentage of analysts from the acquiring and target houses retained at the merged entity.

\begin{tabular}{|c|c|c|c|c|c|c|c|c|}
\hline \multirow[t]{2}{*}{ Brokerage house } & \multirow{2}{*}{$\begin{array}{c}\text { IBES } \\
\text { identifier }\end{array}$} & \multirow{2}{*}{$\begin{array}{l}\text { Merger } \\
\text { date }\end{array}$} & \multicolumn{3}{|c|}{ Stock coverage } & \multicolumn{3}{|c|}{ Analyst outcomes } \\
\hline & & & $\#$ & Overlap & $\begin{array}{l}\text { \%Overlap } \\
\text { retained }\end{array}$ & Pre & Post & \%Retained \\
\hline Paine Webber & 189 & $12 / 31 / 1994$ & 816 & 257 & 63.3 & 52 & 43 & 82.7 \\
\hline Kidder Peabody & 150 & & 722 & & 20.2 & 57 & 10 & 17.4 \\
\hline Morgan Stanley & 192 & $5 / 31 / 1997$ & 1,081 & 283 & 83.1 & 89 & 78 & 87.6 \\
\hline Dean Witter Reynolds & 232 & & 553 & & 12.4 & 39 & 6 & 15.4 \\
\hline Smith Barney (Travelers) & 254 & $11 / 28 / 1997$ & 1367 & 422 & 64.3 & 108 & 81 & 75.0 \\
\hline Salomon Brothers & 242 & & 936 & & 41.4 & 91 & 47 & 51.6 \\
\hline EVEREN Capital & 829 & $1 / 9 / 1998$ & 249 & 17 & 71.4 & 32 & 23 & 71.9 \\
\hline Principal Financial Securities & 495 & & 212 & & 0.0 & 19 & 2 & 10.5 \\
\hline DA Davidson \& Co & 79 & $2 / 17 / 1998$ & 108 & 13 & 52.9 & 7 & 5 & 71.4 \\
\hline Jensen Securities & 932 & & 73 & & 93.8 & 5 & 5 & 100.0 \\
\hline Dain Rauscher & 76 & $4 / 6 / 1998$ & 459 & 37 & 29.2 & 50 & 31 & 62.0 \\
\hline Wessels Arnold \& Henderson & 280 & & 201 & & 45.3 & 17 & 11 & 64.7 \\
\hline First Union & 282 & 10/1/1999 & 417 & 30 & 57.5 & 39 & 30 & 76.9 \\
\hline EVEREN Capital & 829 & & 277 & & 17.9 & 37 & 13 & 35.1 \\
\hline Paine Webber & 189 & $6 / 12 / 2000$ & 758 & 28 & 62.9 & 62 & 49 & 79.0 \\
\hline JC Bradford & 34 & & 229 & & 0.0 & 23 & 0 & 0.0 \\
\hline Credit Suisse First Boston & 100 & $10 / 15 / 2000$ & 1,359 & 452 & 51.5 & 141 & 113 & 80.1 \\
\hline Donaldson Lufkin and Jenrette & 86 & & 1,021 & & 21.5 & 98 & 25 & 25.5 \\
\hline UBS Warburg Dillon Read & 85 & $12 / 10 / 2000$ & 936 & 296 & 49.1 & 121 & 91 & 75.2 \\
\hline Paine Webber & 189 & & 730 & & 49.0 & 67 & 39 & 58.2 \\
\hline JP Morgan & 873 & $12 / 31 / 2000$ & 721 & 88 & 51.8 & 92 & 67 & 69.6 \\
\hline Chase Manhattan & 125 & & 598 & & 41.9 & 50 & 35 & 70.0 \\
\hline Fahnestock & 98 & 9/18/2001 & 161 & 7 & 87.5 & 19 & 12 & 63.2 \\
\hline Josephthal Lyon \& Ross & 933 & & 121 & & 0.0 & 14 & 0 & 0.0 \\
\hline Janney Montgomery Scott & 142 & $3 / 22 / 2005$ & 165 & 8 & 90.0 & 14 & 13 & 92.9 \\
\hline Parker/Hunter & 860 & & 64 & & 10.0 & 5 & 3 & 60.0 \\
\hline
\end{tabular}

at the merging houses, we proceed as follows. First, we locate the $\mathrm{I} / \mathrm{B} / \mathrm{E} / \mathrm{S}$ identifiers of the merging houses and the merged entity (see Table 1 or the Appendix in Hong and Kacperczyk, 2010). Using these identifiers, we extract the analyst identifiers for all analysts issuing an earnings forecast at the merging houses (in the year prior to the merger date) and all analysts issuing a forecast at the merged entity (in the year following the merger date). ${ }^{3}$ The intersection of these two lists is a list of analysts retained at the merged entity. We also extract the respective lists of stocks covered by these analysts, by

\footnotetext{
${ }^{3}$ The analyst identifiers in $\mathrm{I} / \mathrm{B} / \mathrm{E} / \mathrm{S}$ are unique, which allows us to track the career outcomes of analysts.
}

constructing a list of unique stocks (identified by PERMNO) for which an earnings forecast was issued in the year prior to the merger. Two lists are constructed: one list of stocks covered by analysts at the bidding brokerage house and another for target house analysts. The intersection of these two lists is the set of stocks covered by both houses in the year prior to the merger date. For these stocks, there is "overlapping coverage" at the merging houses. These stocks are the focus of this paper and we refer to them as "treated" in what follows.

Table 1 provides the key details on the 13 mergers. We provide the names and $\mathrm{I} / \mathrm{B} / \mathrm{E} / \mathrm{S}$ identification numbers of the merging brokerage houses, listing the acquiring house in the top row of each partition. We provide details on stock coverage at each house, in particular, the number 
of unique U.S. stocks covered by each house in the year prior to the merger date, as well as the overlapping coverage. In the "\% Overlap retained" column, we calculate the percentage of stocks with overlapping coverage that continue to be covered in the year following the merger by analysts retained in the merged entity. The final set of columns describes analyst outcomes in the two years surrounding the merger.

To illustrate our identification strategy, consider the first merger in our sample (see Table 1). This merger took place on December 31, 1994 between Paine Webber and Kidder Peabody. Prior to this merger, there were 257 (treated) stocks that were covered by both Paine Webber and Kidder Peabody. Following the merger, the combined brokerage house ended up with fewer analysts and, in particular, due to redundancy, fewer analysts with overlapping coverage. To be precise, Paine had 52 analysts prior to the merger, Kidder had 57, and the combined entity retained a total of 53 . In this case, the newly formed entity retained $82.7 \%$ of the analysts from the acquiring house, Paine, whereas only $17.4 \%$ of the target house analysts were retained. In the year following the merger at the newly formed entity, $63.3 \%$ of target house analysts retained coverage of treated stocks they were previously covering, whereas only $20.2 \%$ of treated stocks continued to be covered by target analysts following the merger.

We repeat this procedure for the remaining 12 mergers and identify a total of 1,938 (unique) treated stocks. Overall, the same pattern emerges as in the case of Paine Webber's acquisition of Kidder Peabody. On average, stocks with overlapping coverage experience a reduction in coverage in the wake of the merger and coverage tends to be retained at the acquiring house. This is something we verify explicitly in Section 3. We use this variation to identify a causal effect of analyst coverage on financial reporting quality.

To implement our identification strategy, we must choose a time window before and after the merger to be able to establish potential effects brought about by the merger. Contrary to short-term event studies using stock market data, we use lower frequency (annual) accounting data and thus require a longer event window. Following other studies also using brokerage house mergers and balance sheet data (e.g., Derrien and Kecskes, forthcoming), we use a two-year window consisting of one year before (365 days) the merger and one year after the merger. To compute the number of analysts covering a stock around the merger date, we use the same window length. To compute our accounting measures, we use financial statement data from the last fiscal year that ended before the merger as the pre-merger year and the first complete fiscal year after the merger as the post-merger year. For example, if a treatment firm has a December fiscal yearend and the merger date is May 31, 1997, then the premerger year $(t-1)$ would be December 31, 1996 and the post-merger year $(t+1)$ would be December 31,1998 . This results in two non-overlapping observations for all the stocks considered in our sample, one pre- and one post-merger.

The easiest way to test for differences in companies' accounting quality following a reduction in analyst coverage would be to compare the financial reporting quality of treated companies before the shock to the financial reporting quality of treated companies after the shock. This approach neglects, however, potential trends or natural changes that affect all stocks (regardless if included in the treatment sample or not). For instance, new disclosure regulations might lead to increased financial reporting quality for all companies that coincides with the pre- or post-period of a particular merger. By only comparing the pre- and post-differences for treated companies, this could lead us to falsely find an effect in reporting quality and erroneously assign it to the merger.

A common approach to get around these potential time trends is to apply a difference-in-differences (DiD) methodology. By using this methodology, we contrast the changes in the variable of interest that can be observed in the treated companies before and after the shock with the change in the variable of interest that can be observed in the non-treated (i.e., control) companies. In our setting, the treated companies include the stocks that were covered by both merging entities before the merger. The control companies are all other stocks. ${ }^{4}$

One remaining problem with this approach is that the treatment and control companies could significantly differ from each other. In our context, it could be that larger firms tend to be covered by more brokerage houses (and are thus more likely to be a treated firm) but that these companies (due to their size and complexity) are also providers of higher quality financial information. It is thus important to control for such systematic differences in our empirical specification to further isolate the effect of the coverage shock. In Section 3.5, we address this potential concern using two distinct approaches. We first implement a propensity score matching estimator and then we incorporate control variables into our linear regression framework, which we now introduce.

To empirically implement our natural experiment and test how companies react to a shock to their information environment, we use a DiD methodology by running the pooled panel regression

$$
\begin{aligned}
\text { FRQ }_{i}= & \alpha+\beta_{1} \text { POST }_{i}+\beta_{2} \text { TREATED }_{i} \\
& +\beta_{3} \text { POST }_{i} \times \text { TREATED }_{i}+\gamma^{\prime} X_{i}+\epsilon_{i},
\end{aligned}
$$

where $F R Q_{i}$ denotes our measure of financial reporting quality for firm $i, P O S T_{i}$ denotes a dummy variable that is equal to one in the period after the merger and zero otherwise, and TREATED $D_{i}$ is a dummy variable that indicates if a company is part of our treatment sample. Our coefficient of interest is $\beta_{3}$. This coefficient captures the DiD effect, namely, the effect on the financial reporting quality of the treated companies that is due to the merger.

Our preferred specification includes two-digit SIC industry, merger, and firm fixed effects in order to capture time-invariant (possibly unobservable) factors particular to a merger, an industry, or a firm that may influence the reporting behavior across units. This specification accommodates the inclusion of firm-specific control variables (defined below), which are included as part of the vector

\footnotetext{
${ }^{4}$ Our empirical strategy therefore improves upon methodologies that employ regulatory changes such as Regulation Fair Disclosure in 2000 or the Sarbanes-Oxley Act in 2002, which affect all firms during the same time period.
} 
$X_{i}$ on the right-hand side of (1). We estimate this equation using heteroskedasticity-robust standard errors that are clustered at the firm-level. ${ }^{5}$

\subsection{Sample selection}

To implement the identification strategy detailed above, we start constructing our sample by obtaining data on security analyst coverage from $\mathrm{I} / \mathrm{B} / \mathrm{E} / \mathrm{S}$. For each of the 13 mergers that form our identification strategy, we consider a 365-day window around the actual brokerage house merger date. We retain all publicly traded U.S. companies that have an earnings forecast in the 365-day window around every brokerage house merger date. This leaves us with 144,943 firm-year observations.

Next, we merge this sample with balance sheet and income statement data from Standard \& Poor's Compustat. To do so, we must assign fiscal years to the 365-day window before the merger date and the 365-day window after. We assign the last completed fiscal year before the merger date to the 365-day window before the merger date and the first fully completed fiscal year after the merger date to the 365-day window after the merger date. We are able to link 110,482 firm-year observations this way.

We next require that every firm-year observation has the variables necessary to compute our primary measure of financial reporting quality ( $F R Q$ as detailed below), yielding a final sample of 93,005 firm-year observations, which includes 1,179 treated firms. This reduction in sample size is due to missing accounting data, a missing SIC code, or a company belonging to an industry-year with fewer than 15 observations.

In additional specifications, we include control variables (defined below) which include both balance sheet and securities price data from the merged CRSP/Compustat database. Constructing these control variables imposes additional data requirements and reduces the sample for these analyses to 39,384 firm-year observations.

Appendix B provides a detailed breakdown of the sample construction for each of the samples used in our main set of analyses. Appendix B also provides the distribution of treated and control firms and firm-years for each of these samples.

\subsection{Measuring financial reporting quality}

We use an accruals-based measure to construct our main variable of financial reporting quality (FRQ). Accounting adjustments can be used to split earnings up into cash flows and accruals. Both the size and sign of accruals are subject to management's judgement and can be used to manipulate reported earnings. Managerial discretion in the use of accruals can make it harder for

\footnotetext{
${ }^{5}$ We have experimented with various different clusterings (e.g., by merger, industry, merger and industry), obtaining similar results. Clustering standard errors at the firm-level generally produces the most conservative (largest) standard errors, so we report these throughout the paper.
}

outsiders to evaluate the true economic content of firms' financial statements.

We construct FRQ as follows. First, we estimate the "normal" level of accruals for a particular firm, using coefficients obtained from industry-level cross-sectional models of accruals. The advantage of such a crosssectional measure is that it helps us overcome the severe data restrictions and survivorship bias that time-series models impose. Furthermore, given our interest in yearto-year changes around the merger dates, a time-series estimate would not be appropriate.

To compute the normal level of accruals, we use the Jones model (Jones, 1991) in its modified version (Dechow, Sloan, and Sweeney, 1995). We first run the cross-sectional regression for each two-digit SIC industry and each year

$\frac{T_{i t}}{\operatorname{ASSETS~}_{i, t-1}}=b_{1} \frac{1}{\operatorname{ASSETS~}_{i, t-1}}+b_{2} \frac{\Delta R E V_{i t}}{\operatorname{ASSETS~}_{i, t-1}}+b_{3} \frac{\operatorname{PPE}_{i t}}{\operatorname{ASSETS~}_{i, t-1}}+\epsilon_{i t}$,

where $T A_{i t}$ denotes total accruals of firm $i$ in year $t$, calculated as the difference between net income (Compustat item $\mathrm{ni}$ ) and cash flow from operations (item oancf), $\triangle R E V$ is the difference in sales revenues (item sale), and $P P E$ is gross property, plant, and equipment (item ppegt). All variables are scaled by lagged total assets (item at). ${ }^{6}$

The coefficients from estimating (2) are then used to estimate the firm-level normal accruals $(N A)$ for each firm

$\frac{N A_{i t}}{\operatorname{ASSETS~}_{i, t-1}}=\widehat{b}_{1} \frac{1}{\operatorname{ASSETS~}_{i, t-1}}+\widehat{b}_{2} \frac{\Delta \text { REV }_{i t}-\Delta A R_{i t}}{\operatorname{ASSETS}_{i, t-1}}+\widehat{b}_{3} \frac{\text { PPE }_{i t}}{\operatorname{ASSETS~}_{i, t-1}}$,

where $\triangle A R$ is the change in receivables (item rect) and the other variables are the same as above. Next, we calculate our measure of financial reporting quality, $F R Q$, as the absolute difference between total accruals and the predicted firm-level normal accruals (abnormal accruals):

$F R Q_{i t}=\left|T A_{i t}-N A_{i t}\right|$

We interpret large absolute abnormal accruals as an indication of relatively high differences between the cash flows and the earnings of a firm. Large abnormal accruals thus make it harder for investors to learn about the true economic performance of a company and indicate lower financial reporting quality. We attenuate the distortions arising from extreme outliers by trimming our FRQ variable at the $95 \%$ level.

We use a number of alternative measures of financial reporting quality. First, we use two non-regression-based measures of current accruals to overcome potential weaknesses of regression-based accounting quality measures. Following the accounting literature (e.g., Sloan, 1996),

${ }^{6}$ We have experimented with other industry classifications such as the 48 Fama-French industries. None of our results are qualitatively affected by employing alternative industry classifications. 
we calculate the current accruals as

$C A_{i t}=\frac{\Delta C \cdot \text { ASSETS }_{i t}-\Delta C L_{i t}-\Delta C A S H_{i t}-D E P_{i t}}{\text { ASSETS }_{i, t-1}}$,

where $\triangle C$.ASSETS is the change in current assets (item $a c t$ ), $\triangle C L$ is the change in current liabilities (item lct), $\triangle C A S H$ is the change in cash holdings (item che), and DEP is the depreciation and amortization expense (item $d p$ ). We exclude short-term debt from current liabilities, since managers will lack discretion over this item in the short run (Richardson, Sloan, Soliman, and Tuna, 2005). We take the absolute value of these current accruals as our measure of financial reporting quality.

We also consider a variant of this current accruals, calculated by removing depreciation from the right-hand side of (5). The motivation for removing depreciation comes from Barton and Simko (2002), which argues that managers have limited discretion over depreciation schedules in the short run. We label this measure "CA (exc. depr)."

The third non-regression-based measure we use follows Hribar and Collins (2002), who show that using successive annual balance sheet variables creates potential problems in the estimation of accruals for companies with merger and acquisitions activities, significant foreign currency accounts, or discontinued operations. They propose a total accruals measure that is not subject to this problem and is calculated as

$C A(\text { cash flow })_{i t}=\frac{E B X I_{i t}-C F O_{i t}}{A S S E T S_{i, t-1}}$,

where EBXI denotes earnings before extraordinary items and discontinued operations (item $i b c$ ) and $C F O$ is the operating cash flows from continuing operations taken from the statement of cash flows (item oancf-item xidoc). This measure also aims to identify differences between earnings and cash flows, but it is based on data from the income and cash flows statement and not the balance sheet.

We also consider measures of financial reporting quality that are not directly constructed from accounting data. To this end, we utilize two statistics to measure annual report readability, introduced to the accounting literature by Li (2008) and kindly provided to us by the author.

To construct his sample, the author first downloads all $10-\mathrm{K}$ annual reports that were filed electronically with the Securities and Exchange Commission (SEC) using the online Electronic Data-Gathering, Analysis, and Retrieval (EDGAR) system. This restricts the sample to begin in 1994, as this was the first year that EDGAR was phased in. The remaining firms are hand-matched to CRSP/Compustat via unique firm identifiers used by the EDGAR system (the Central Index Key). To prepare for calculation of annual report readability, the matched electronic $10-\mathrm{K}$ filings are edited to exclude heading items, paragraphs with fewer than one line, and tables. ${ }^{7}$ As a final filter, $10-\mathrm{K}$

\footnotetext{
${ }^{7}$ Readability measures are designed for text rather than numbers or tables, which is why it is important to edit the electronic 10-K filings in this way.
}

filings with fewer than 3,000 words or one hundred lines are dropped.

We consider the Fog index (FOG), a measure of readability used extensively in the computational linguistics literature. This measure captures text complexity as a function of syllables per word and words per sentence. ${ }^{8}$ It is calculated as

$F O G_{i t}=0.4$.(words per sentence + percent of complex words),

where complex words are defined as words with three or more syllables. ${ }^{9}$

We complement the Fog index with the raw number of words contained in the annual report (NWORDS). Following Li (2008), we interpret longer, less readable financial reports (greater FOG) as consistent with lower quality financial reporting.

\subsection{Measuring corporate governance}

To capture corporate governance we use four different variables. Each of these variables is measured at the firm level.

Our first measure of corporate governance is the G-index (G-INDEX), which aggregates information on shareholder rights at the firm-level (Gompers, Ishii, and Metrick, 2003). As has been argued in the literature, governance (or anti-takeover) provisions serve as a means of insulating (entrenching) management from the disciplining effects of shareholders and the market for corporate control. We obtain data on the $\mathrm{G}$-index from the Investor Responsibility Research Center (IRRC, now RiskMetrics) database. This index assigns a value of one to each of 24 firm-level governance provisions and is computed as the sum of these provisions. For a given firm, a high G-index corresponds to the presence of more provisions protecting management-for example, making takeovers more costly to execute-and thus leading to more entrenched management. These data are available for the years 1993, 1995, 1998, 2000, 2002, 2004, and 2006 during our sample period. For intermediate years, we follow the existing literature and use the G-index from the latest year available.

We also use the "entrenchment index," E-index (E-INDEX), proposed by Bebchuk, Cohen, and Ferrell (2009). The E-index consists of six of the aforementioned 24 anti-takeover provisions used to construct the G-index. ${ }^{10}$ These authors show that this subset of provisions largely drives the (negative) empirical correlation between the IRRC provisions and firm valuation since 1990 . As such, the E-index could be viewed as

\footnotetext{
${ }^{8}$ The actual index itself denotes the number of years of formal education that a reader of average intelligence would require in order to read and understand the text with one viewing only.

9 The Lingua::EN:Fathom Perl package is used to analyze the edited $10-\mathrm{K}$ filings and calculate these two statistics. This program is commonly used in other fields, such as information science (e.g., CollinsThompson and Callan, 2005).

${ }^{10}$ The subset of provisions considered in the E-index are: staggered boards, limits to shareholder bylaw amendments, poison pills, golden parachutes, and supermajority requirements for mergers and charter amendments.
} 
a less noisy proxy of corporate governance. We obtain data on the E-index from Lucian Bebchuk's web page.

Third, we obtain data on firms' dual-class ownership structure $(D U A L)$ from the RiskMetrics database. Firms with dual-class structure have at least two equity share classes, each with different voting rights. ${ }^{11}$ The most common case involves two classes of equity shares, one class with ten votes per share and the other class with only one vote per share (Gompers, Ishii, and Metrick, 2010). The class of shares with stronger voting rights is typically held by insiders of the firm, as a means of separating control from cash-flow rights. With such voting rights in place, management is potentially more entrenched and subject to less discipline imposed by outside stakeholders, relative to management at firms with a single-class share structure.

Finally, we consider whether firms have a Chief Executive Officer (CEO) that is also the chairman of the board of directors at the same time, referred to as "CEO-chairman duality” (e.g., Brickley, Coles, and Jarrell, 1997; Jensen, 1993). The function of the chairman of the board is (among other things) to oversee the process of hiring, compensating, and firing the CEO. When the chairman of the board is the CEO himself, the internal control system of monitoring and disciplining management is plausibly weakened. We obtain data on dual CEO-chairman from the RiskMetrics Directors database and for each firm-year define a variable (CC-DUAL) equal to one if the CEO has a dual role as chairman.

Since IRRC/RiskMetrics only covers companies in the Standard \& Poors (S\&P) 1500 index, our sample is reduced for the analyses including governance variables. Specifically, using the G-index $(21,223)$, E-index $(21,223)$, or the dual share class $(21,223)$, and using data on CEO/chairman duality leaves us with 20,999 firm-year observations.

\subsection{Control variables}

Our empirical setup enables us to add control variables to our main specification. Incorporating these variables into our analysis mitigates concerns regarding observable differences among treated and control firms driving any estimated average treatment effect. When choosing control variables, we follow prior research that also uses a measure of financial reporting quality or disclosure as a dependent variable (e.g., Anantharaman and Zhang, 2012; Armstrong, Balakrishnan, and Cohen, 2012; Bergstresser and Philippon, 2006; Li, 2008).

We include the logarithm of a firm's market capitalization (LNSIZE), where a firm's market capitalization is calculated as the number of common shares outstanding times price (both variables are obtained from CRSP). ${ }^{12}$ We include the average of the previous 12 monthly returns of a particular stock (RETANN). We include the natural logarithm of a company's book value divided by its market capitalization ( $L N B M)$. We include a company's

\footnotetext{
11 See Gompers, Ishii, and Metrick (2010) for an in-depth analysis of the value-implications of the dual-class share structure.

${ }^{12}$ When obtaining data from CRSP, we restrict our sample to share codes 10 and 11 .
}

return on equity $(R O E)$, where $(R O E)$ is calculated as earnings (defined as income before extraordinary items available for common stockholders (item ibcom) plus deferred taxes (item txdi) plus investment tax credit (item itci) divided by a company's book value of equity). We also include the volatility of $R O E$, computed from an AR(1) model for a firm's past ten annual values of $R O E$ (VOLROE). Finally, from I/B/E/S, we include the number of unique analysts covering a particular firm in a given fiscal year (COVERAGE).

The data requirements imposed by these additional control variables leave us with a sample of 39,384 firmyear observations. The summary statistics for these variables for both treatment and control samples are presented in Table 2. Panel A of Table 2 presents the summary statistics for the financial reporting quality variables. Panels $B$ and $C$ summarize the control and corporate governance variables, respectively.

As mentioned in Hong and Kacperczyk (2010), the treated firms are larger and have more coverage than the average Compustat firm. These differences occur for two reasons. First, treated firms must be covered by at least two brokerage houses. Second, the majority of treated firms are involved with the large brokerage house mergers (i.e., mergers $1,2,3,9$ and 10, as detailed in Table 1) and large houses tend to cover large firms.

The treatment and control samples differ along several of the other observable dimensions shown in Table $2 .{ }^{13}$ In a series of robustness tests, we will demonstrate that our results are not confounded by these ex ante differences in observables.

\section{Results}

We begin by validating our experiment and then quantify the average effect of an exogenous loss of coverage on financial reporting quality (Section 3.1). We then consider how the loss of coverage interacts with measures of corporate governance at the firm-level (Section 3.2). In Section 3.4, we consider the role of financial constraints and conclude our empirical analysis with a series of robustness tests.

\subsection{Average treatment effect}

We begin by validating the key idea of the experiment: on average, treated firms should lose about one analyst relative to non-treated firms in the period around the brokerage house merger. We test this by replacing FRQ with analyst coverage (COVERAGE) on the left-hand side variable in (1). If our experimental design is valid, we expect the estimated $\mathrm{DiD}$ term to be roughly equal to minus one and statistically significant.

The first column of Table 3 confirms that this is the case. The estimated coefficient is -1.12 with a $t$-value of -3.7. This is consistent in terms of size and significance

\footnotetext{
13 Two-tailed difference in means tests (unreported) confirm this statement. In particular, all variables in Table 2 have different means at the $5 \%$ level of statistical significance, with the exception of FOG, VOLROE, SALESGR, and E-INDEX.
} 
Table 2

Summary statistics for the treatment and control samples.

This table reports summary statistics for our treatment and control samples in the year prior to merger. The treatment sample consists of all stocks covered by two merging brokerage houses around the one-year merger window. The control sample is the remainder of the Compustat universe with the required data. Panel A reports summary statistics for the financial reporting quality variables. Panel B reports summary statistics for the control variables. All variables are defined in Appendix A.

\begin{tabular}{|c|c|c|c|c|c|c|c|c|c|c|c|c|}
\hline \multirow[t]{2}{*}{ Variable } & \multicolumn{6}{|c|}{ Treated firms } & \multicolumn{6}{|c|}{ Control firms } \\
\hline & $N$ & Mean & Q1 & Median & Q3 & Std. dev. & $N$ & Mean & Q1 & Median & Q3 & Std. dev. \\
\hline \multicolumn{13}{|c|}{ Panel A: Financial reporting quality variables } \\
\hline FRQ & 1,179 & 0.1187 & 0.0164 & 0.0460 & 0.1179 & 0.2085 & 45,324 & 0.1664 & 0.0299 & 0.0777 & 0.1922 & 0.1663 \\
\hline$C A$ & 1,180 & 0.0681 & 0.0361 & 0.0561 & 0.0915 & 0.0528 & 45,786 & 0.0843 & 0.0359 & 0.0652 & 0.1147 & 0.0654 \\
\hline CA (Cash Flow) & 1,276 & 0.0767 & 0.0396 & 0.0610 & 0.1048 & 0.0631 & 46,849 & 0.0977 & 0.0382 & 0.0723 & 0.1298 & 0.0827 \\
\hline CA (exc. Depr.) & 1,180 & 0.0400 & 0.0098 & 0.0240 & 0.0515 & 0.0485 & 45,786 & 0.0637 & 0.0163 & 0.0408 & 0.0874 & 0.0674 \\
\hline FOG & 614 & 19.29 & 18.35 & 19.22 & 20.08 & 1.40 & 36,881 & 19.38 & 18.44 & 19.25 & 20.18 & 1.58 \\
\hline NWORDS & 614 & 37,282 & 19,950 & 28,546 & 45,189 & 28,705 & 36,881 & 21,876 & 16,116 & 23,894 & 38,292 & 27,162 \\
\hline \multicolumn{13}{|c|}{ Panel B: Control variables } \\
\hline COVERAGE & 1,088 & 24.05 & 17 & 23 & 31 & 10.36 & 18,604 & 10.86 & 5 & 9 & 14 & 7.82 \\
\hline LNSIZE & 1,088 & 8.5176 & 7.3975 & 8.4573 & 9.5294 & 1.5656 & 18,604 & 6.7176 & 5.6524 & 6.6031 & 7.6927 & 1.5964 \\
\hline RETANN & 1,088 & 0.0107 & -0.0037 & 0.0128 & 0.0284 & 0.0371 & 18,604 & 0.0105 & -0.0116 & 0.0108 & 0.0337 & 0.0598 \\
\hline$L N B M$ & 1,088 & -1.0910 & -1.5742 & -0.9642 & -0.4663 & 0.9453 & 18,604 & -0.8989 & -1.3924 & -0.8252 & -0.3350 & 0.8661 \\
\hline SIGMA & 1,088 & 0.4233 & 0.2574 & 0.3803 & 0.5291 & 0.2188 & 18,604 & 0.5246 & 0.3339 & 0.4233 & 0.6605 & 0.2530 \\
\hline VOLROE & 1,088 & 0.2498 & 0.0593 & 0.1031 & 0.2134 & 0.4035 & 18,604 & 0.2420 & 0.0632 & 0.1217 & 0.2585 & 0.3260 \\
\hline$N E I$ & 1,134 & 1.0816 & 0.9956 & 1.0060 & 1.0340 & 0.3272 & 45,031 & 1.1375 & 1.0000 & 1.0117 & 1.0943 & 0.4072 \\
\hline SALESGR & 1,179 & 0.1575 & 0.0246 & 0.1002 & 0.2621 & 0.2336 & 44,756 & 0.1489 & 0.0316 & 0.1305 & 0.3489 & 0.3544 \\
\hline \multicolumn{13}{|c|}{ Panel C: Governance variables } \\
\hline$G-I N D E X$ & 671 & 9.3159 & 7 & 9 & 11 & 2.7904 & 9,941 & 8.9058 & 7 & 9 & 11 & 2.7333 \\
\hline E-INDEX & 671 & 2.1356 & 1 & 2 & 3 & 1.3695 & 9,941 & 2.2303 & 1 & 2 & 3 & 1.3281 \\
\hline$D U A L$ & 671 & 0.0730 & 0 & 0 & 0 & 0.2604 & 9,941 & 0.1059 & 0 & 0 & 0 & 0.3077 \\
\hline$C C-D U A L$ & 604 & 0.6656 & 0 & 1 & 1 & 0.4722 & 9,896 & 0.6000 & 0 & 1 & 1 & 0.4899 \\
\hline
\end{tabular}

with research using a similar experimental design (e.g., Derrien and Kecskes, forthcoming; Hong and Kacperczyk, 2010), despite sample selection differences arising from various data restrictions in these other studies. ${ }^{14}$

Next, we examine the impact of this loss of coverage on the disclosure behavior of the firm. The remaining columns of Table 3 present these results. Column 2 displays the results from estimating (1) without any control variables or fixed effects. From this regression, we see that the DiD coefficient, $\beta_{3}$, is positive and statistically significant. The point estimate on the DiD term in column 2 is 0.30 , indicating that a drop in coverage in our treatment sample results in an increase in abnormal discretionary accruals that is about $12 \%$ of one standard deviation. Thus, the effect we document is not only statistically but also economically significant.

Given our construction of $F R Q$ this means that following the merger of two brokerage houses, affected firms' financial accounting figures contain a higher amount of abnormal accruals, i.e., a bigger abnormal gap between

\footnotetext{
${ }^{14}$ In unreported results, we also confirm the finding of Hong and Kacperczyk (2010) that the mergers result in an increase in the analyst forecast error variance associated with earnings per share estimates for treated firms' stocks. Moreover, we also confirm that the reduction in coverage is concentrated at the target brokerage house. In our setting, these two results are important because they alleviate concerns that the coverage reduction is related to the skill of the analyst-there is a fixed rule for firing analysts that is orthogonal to analyst skill—and that while the quantity of information (i.e., monitoring) is reduced, the quality is not.
}

cash flows and earnings. Our interpretation of this adjustment is that firms react to changes in the information production and monitoring by securities analysts by lowering the quality of their financial reporting. This finding is consistent with economic models of fraudulent accounting and misreporting (e.g., Kedia and Philippon, 2009). In such models, when management faces a lower probability of detection by external monitors, it will have a greater incentive to rent-seek and conceal true firm performance.

In columns 3-5, we run the same analysis as in column 2 but include a battery of fixed effects. These fixed effects address concerns regarding time-invariant factors that could affect disclosure behavior across groups. In column 3 , we include merger fixed effects and the estimated DiD is virtually unchanged in both magnitude and statistical significance. Additionally including industry and, finally, industry and firm fixed effects does not change the overall picture. Across all specifications, the estimated partial effect of the merger on the treated firms remains statistically significant and on the same order of magnitude. This assures us the estimate is not due to systematic differences in reporting behavior across mergers, industries, or firms.

In columns 6 and 7, we test whether the reduction in financial reporting quality is more pronounced for firms with lower initial analyst coverage. We would reasonably expect those firms facing a greater percentage reduction in coverage to adjust their behavior more sharply. To this end, we split our treatment sample into two groups, 
Table 3

Change in FRQ: difference-in-differences estimation.

This table reports results from the estimation of the pooled panel regression in (1). For each merger, we consider a one-year window prior to the merger (pre-merger window) and a one-year window after the merger (post-merger window). The dependent variable is either COVERAGE or FRQ. FRQ is trimmed at the 95\% level. POST is a variable that is equal to one for the post-merger period and zero for the pre-merger period. For each merger, we construct an indicator variable (TREATED) which is equal to one for each stock covered by both merging brokerage houses (treatment sample) and zero otherwise. In the last two columns, we split up our treatment sample according to COVERAGE and run our baseline specification for two subsamples. The High (Low) initial coverage subsample includes all control firm-years and the treated firm-years that have higher (lower) COVERAGE than the median treated firm-year. If indicated, the regressions include two-digit SIC industry, merger, or firm fixed effects. $t$-Values (in parentheses) are robust to clustering at the firm-level. ${ }^{* * *},{ }^{* *},{ }^{*}$ Denote $1 \%, 5 \%$, and $10 \%$ statistical significance. All variables are defined in Appendix A.

\begin{tabular}{|c|c|c|c|c|c|c|c|}
\hline & \multirow[b]{2}{*}{ COVERAGE } & \multirow[b]{2}{*}{ FRQ } & \multirow[b]{2}{*}{$F R Q$} & \multirow[b]{2}{*}{$F R Q$} & \multirow[b]{2}{*}{ FRQ } & \multicolumn{2}{|c|}{ Initial coverage } \\
\hline & & & & & & High & Low \\
\hline POST & $\begin{array}{l}0.426^{* *} \\
(2.818)\end{array}$ & $\begin{array}{c}-0.002 \\
(-0.158)\end{array}$ & $\begin{array}{c}0.001 \\
(0.100)\end{array}$ & $\begin{array}{c}0.000 \\
(0.000)\end{array}$ & $\begin{array}{c}0.002 \\
(0.118)\end{array}$ & $\begin{array}{c}0.002 \\
(0.813)\end{array}$ & $\begin{array}{c}-0.002 \\
(-0.158)\end{array}$ \\
\hline TREATED & $\begin{array}{l}16.950^{* * * * *} \\
(21.617)\end{array}$ & $\begin{array}{l}-0.048^{* * *} \\
(-2.811)\end{array}$ & $\begin{array}{l}-0.044^{* * * k} \\
(-3.839)\end{array}$ & $\begin{array}{l}-0.020^{* * *} \\
(-2.165)\end{array}$ & $\begin{array}{c}-0.005 \\
(-0.765)\end{array}$ & $\begin{array}{c}0.004 \\
(0.416)\end{array}$ & $\begin{array}{l}-0.048^{* *} \\
(-2.811)\end{array}$ \\
\hline$P O S T \times T R E A T E D$ & $\begin{array}{l}-1.120^{* * * *} \\
(-3.717)\end{array}$ & $\begin{array}{l}0.030^{* * k} \\
(2.420)\end{array}$ & $\begin{array}{l}0.028^{* * *} \\
(2.346)\end{array}$ & $\begin{array}{l}0.027^{* * *} \\
(2.182)\end{array}$ & $\begin{array}{c}0.025^{*} \\
(2.126)\end{array}$ & $\begin{array}{c}0.011 \\
(0.658)\end{array}$ & $\begin{array}{r}0.030^{* *} \\
(2.420)\end{array}$ \\
\hline Merger fixed effects & No & No & Yes & Yes & Yes & Yes & Yes \\
\hline Industry fixed effects & No & No & No & Yes & Yes & Yes & Yes \\
\hline Firm fixed effects & No & No & No & No & Yes & Yes & Yes \\
\hline Number of observations & 93,005 & 93,005 & 93,005 & 93,005 & 93,005 & 93,005 & 93,005 \\
\hline$R$-squared & 0.111 & 0.001 & 0.034 & 0.190 & 0.419 & 0.420 & 0.420 \\
\hline
\end{tabular}

"High" and "Low" initial coverage, depending on whether coverage in the year prior to the merger is above or below the median among treated firms. Mean coverage in the Low (High) initial coverage subgroup is 12.4 (29.7). We then estimate our baseline model on each group separately. The results indicate that the cross-sectional effect is concentrated among firms in the low coverage subsample, which are firms where the loss of one analyst represents a larger percentage drop in monitoring. For this group, the estimated DiD coefficient is positive and statistically significant. This is not the case for the high coverage subgroup. ${ }^{15}$

Overall, our baseline results indicate that an exogenous reduction in analyst coverage causes lower quality financial reporting, consistent with the role of analysts as external monitors.

\subsection{Does corporate governance matter?}

Having established a causal relation between analyst coverage and disclosure, we now aim to further understand to what extent analyst monitoring serves as a substitute or complement to traditional corporate governance mechanisms.

Analysts undertake private information gathering and scrutinize managerial behavior. Traditional governance devices such as the board of directors, prospective

\footnotetext{
${ }^{15}$ In unreported results, we also consider treated firms that lose all coverage after the merger. This results from the stock being dropped by the merged entity altogether. We re-estimate our baseline regression model (including merger, industry, and firm fixed effects) for this subsample and find our average effect increases in magnitude and remains statistically significant $\left(\beta_{3}=0.098\right.$, significant at $10 \%$ level). This is consistent with a monitoring channel. However, we interpret this finding with caution, as the decision to drop coverage at the merged entity is no longer driven by the redundancy (i.e., multiple analysts covering the same stock in merged entity) that is key to our empirical design.
}

acquirers, and other institutions also perform this same function. Analysts exercise market discipline through information revelation in earnings forecasts, whereas internal governance mechanisms discipline misbehaving managers directly through compensation and dismissal.

While the nature of these information gathering and processing activities may differ across agents, both analysts and governance mechanisms are essentially performing the same task. Both devices have the purpose of monitoring and imposing discipline on value-destroying managers. With good governance, managers will already be appropriately incentivized and rent-seeking behavior will be mitigated. Thus, in the presence of good internal and external governance, the marginal incentive contribution through analyst monitoring might be smaller. This first view suggests that monitoring by security analysts serves as an independent alternative-or a substitute-to traditional corporate governance.

The alternative view is that there is a complementarity between monitoring by analysts and other governance mechanisms. For example, information produced and disseminated by analysts might inform the board of directors leading to an improvement in their ability to discipline management.

Distinguishing between these two hypotheses is the empirical question that we now pursue. In our empirical framework, this amounts to testing to see whether the partial (positive) effect of analyst coverage on financial reporting quality varies in the cross-section with firmlevel measures of corporate governance.

If the substitution hypothesis is true, this would be evidenced by a smaller partial effect of coverage on reporting quality among the well-governed firms. We would expect that well-governed firms are less affected by the loss of coverage. Management of these firms has already been incentivized to follow an optimal disclosure policy. 
On the other hand, under the complementarity hypothesis, we would also expect to see a deterioration in reporting quality among well-governed firms. Under this hypothesis, analyst coverage and corporate governance at these firms are mutually reinforcing monitoring devices. Therefore, the loss of information produced by analysts will reduce the efficacy of other governance devices, which will be reflected in a reduction of the quality of financial reporting for both poorly and well-governed firms.

To implement this test we use four firm-level measures of corporate governance: the G-index, E-index, CEOchairman duality, and dual-class share status. These variables are defined and discussed in detail in Section 2.4. The governance measures that we employ are generally only available for Standard \& Poor's 1500 companies, so our sample is reduced. ${ }^{16}$

To examine whether the treatment effect is different for "good" and "bad" governance firms, respectively, we estimate a multiple treatment effects model variant of (1) in which the treatment dummy is interacted with dummies indicating whether the firm is well or poorly governed:

$$
\begin{aligned}
\text { FRQ }_{i}= & \alpha+\beta_{1} \text { POST }_{i}+\beta_{2} \text { TREATED }_{i} \\
& +\beta_{3} \text { POST }_{i} \times \text { TREATED }_{i} \times \text { BAD }_{i} \\
& +\beta_{4} \text { POST }_{i} \times \text { TREATED }_{i} \times \text { GOOD }_{i}+\gamma^{\prime} X_{i}+\epsilon_{i},
\end{aligned}
$$

where $B A D(G O O D)$ is a dummy variable equal to one if a given firm-year treated observation is classified as "poorly" (well) governed (in the year prior to treatment), where the classification is defined below.

The results of our tests are shown in Table 4. For all four governance measures, we find evidence consistent with the substitution hypothesis.

We first consider the G-index. This measure aggregates 24 anti-takeover provisions (see Gompers, Ishii, and Metrick, 2003). We classify treatment firm-year observations as well-governed $(G O O D=1$ and $B A D=0)$ if the observation falls below the treated sample median (i.e., 9) in the period prior to the merger event. The other treated firm observations are classified as poorly governed and the dummy variables are defined accordingly. Recall a higher value of the G-index corresponds to weaker shareholder rights and more entrenched management.

As column 1 shows, the estimated marginal effect of analyst coverage on financial reporting quality for firms with weak governance is positive and significant. The DiD coefficient is larger in magnitude $\left(\beta_{3}=0.043\right)$ than the corresponding average treatment effect (ATE) for the full sample (see Table 3, column 5 ) and significant at the $1 \%$ level. On the other hand, the estimated treatment effect is small in magnitude and indistinguishable from zero in the case of well-governed treated firms. ${ }^{17}$ The loss of

\footnotetext{
${ }^{16}$ As can be seen from Table 2, we are losing mostly control firms. In unreported results, we verify that the estimated average treatment effect is virtually indistinguishable from that obtained using the full sample, as in Table 3.

17 For robustness, we redefine our comparison groups to be the top and bottom quartiles of the G-index distribution. We exclude treated firms in the middle two quartiles of the G-index distribution, assuming these observations only differ by a noise component. We then reestimate (8) and find the point estimate on the poorly governed group $\left(\beta_{3}\right)$ increases in magnitude and remains significant at the $1 \%$ level.
}

coverage does not lead to an adjustment in disclosure behavior among the well-governed subset of treated firms. This evidence supports the substitution hypothesis.

In column 2 we examine an alternative proxy for managerial entrenchment, the E-index of Bebchuk, Cohen, and Ferrell (2009). This measure focuses on six of the 24 IRRC anti-takeover provisions shown to drive the correlation between governance and firm value. As before, we classify treated firm-years as well-governed if the E-index in the year prior to the relevant merger event is below the median and as poorly governed otherwise. We find an almost identical result to the $\mathrm{G}$-index $\left(\beta_{3}=0.040, t=2.897\right.$ ) with the statistical significance of the DiD coefficients on the same order of magnitude.

Next, in column 3, we consider CEO-chairman duality as another governance proxy. If a company has a CEOchairman duality, then the CEO also serves as the chairman of the board of directors. We find a qualitatively similar result that the partial effect of analyst coverage on disclosure is stronger for firms where the CEO also plays the role of chairman. The estimated treatment effect on coverage on reporting is positive, statistically significant, and only present for treated firm-years with the CC-DUAL dummy equal to one, consistent with our findings so far.

Finally, we examine whether firms that adopt a dualclass share structure respond differently to the loss of coverage. Firms with a dual-class share structure have multiple classes of shares with different voting rights. Typically, there is a class of shares retained by management (or founders) with superior voting rights (e.g., ten votes per share). As argued in Gompers, Ishii, and Metrick (2010), management of firms with a dual-class share structure is subject to less scrutiny from shareholders.

The results are presented in column 4 , which displays the average treatment effect of the coverage shock on financial reporting quality for firms with $(D U A L=1)$ and without $(D U A L=0)$ a dual-class share structure. First, note that the dual-class firms' reporting quality responds sharply to the loss of coverage. This is true in terms of economic magnitude, but not for statistical significance. This is due to the small number of firm-year observations with a dual-class share structure in our sample. Encouragingly, the estimated treatment effect for dual-class firms is on the same order of magnitude as the corresponding treatment effects in columns 1-3 and the treatment effect for single-class share structure firms is close to zero in magnitude. The difference in treatment effects between the well- and poorly governed firms ( 0.031 versus 0.007$)$ suggests that the marginal value of analyst coverage is particularly high among firms adopting this rather "extreme" form of (weak) governance.

To summarize the results of this section, we find that the marginal value of analyst coverage is higher in the presence of weak shareholder rights (i.e., if the manager is more entrenched). Among the set of well-governed firms, we observe a smaller (and often no) adjustment in

(footnote continued)

The same adjustment of our approach for the analyst coverage split in Table 3 also yields stronger results. 
Table 4

Does corporate governance matter?

This table reports results from the estimation of (8), with the treatment effect interacted with governance characteristics. For all specifications, the dependent variable is FRQ. For each of the governance characteristics we consider, we split up the treatment group into two groups and define an indicator variable accordingly. In the first (second) column, treated firm-years are classified into two groups depending on whether a company's G-(E)index is above or below the median. In the third (fourth) column, we split the treatment group into two groups depending on whether a company has a combined CEO-chairman of the board (dual-class share structure) or not. POST is a variable that is equal to one for the post-merger period and zero for the pre-merger period. For each merger, we construct an indicator variable (TREATED) which is equal to one for each stock covered by both merging brokerage houses (treatment sample) and zero otherwise. Regressions include two-digit SIC industry, merger, and firm fixed effects. $t$-Values (in parentheses) are robust to clustering at the firm level. ***, *** * Denote $1 \%, 5 \%$, and $10 \%$ statistical significance. All variables are defined in Appendix A.

\begin{tabular}{|c|c|c|c|c|}
\hline$F R Q$ & G-index & E-index & C/C Duality & Dual class \\
\hline POST & $\begin{array}{c}0.003 \\
(0.997)\end{array}$ & $\begin{array}{c}0.003 \\
(1.004)\end{array}$ & $\begin{array}{l}0.007^{* * *} \\
(2.045)\end{array}$ & $\begin{array}{c}0.005 \\
(1.586)\end{array}$ \\
\hline TREATED & $\begin{array}{l}-0.005 \\
(-0.648)\end{array}$ & $\begin{array}{l}-0.005 \\
(-0.666)\end{array}$ & $\begin{array}{c}-0.003 \\
(-0.345)\end{array}$ & $\begin{array}{c}0.010^{*} \\
(1.765)\end{array}$ \\
\hline$P O S T \times$ TREATED $\times 1(>$ median $)$ & $\begin{array}{l}0.043^{* * * *} \\
(3.002)\end{array}$ & $\begin{array}{l}0.040^{* * * *} \\
(2.897)\end{array}$ & & \\
\hline$P O S T \times$ TREATED $\times 1(<$ median $)$ & $\begin{array}{c}0.017 \\
(0.927)\end{array}$ & $\begin{array}{c}0.018 \\
(0.897)\end{array}$ & & \\
\hline$P O S T \times T R E A T E D \times 1(C C-D U A L=1)$ & & & $\begin{array}{l}0.033^{* * *} \\
(2.011)\end{array}$ & \\
\hline$P O S T \times T R E A T E D \times 1(C C-D U A L=0)$ & & & $\begin{array}{c}0.017 \\
(0.834)\end{array}$ & \\
\hline$P O S T \times T R E A T E D \times 1(D U A L=1)$ & & & & $\begin{array}{c}0.031 \\
(0.834)\end{array}$ \\
\hline$P O S T \times T R E A T E D \times 1(D U A L=0)$ & & & & $\begin{array}{c}0.007 \\
(0.483)\end{array}$ \\
\hline Merger fixed effects & Yes & Yes & Yes & Yes \\
\hline Industry fixed effects & Yes & Yes & Yes & Yes \\
\hline Firm fixed effects & Yes & Yes & Yes & Yes \\
\hline Number of observations & 21,223 & 21,223 & 20,999 & 21,223 \\
\hline$R$-squared & 0.397 & 0.397 & 0.430 & 0.397 \\
\hline
\end{tabular}

reporting behavior immediately following the exogenous coverage shock. Our interpretation is that management's disclosure behavior is already close to optimal in the presence of these alternative governance mechanisms. Thus, consistent with the substitution hypothesis, scrutiny by analysts plays no role in disciplining managerial misreporting.

\subsection{Dynamic effects of mergers}

In this section, we expand our results in Table 3 by estimating the effect of the brokerage house mergers on coverage and financial reporting quality for the treatment sample up to three years ahead. This allows us to investigate whether the mergers had a permanent or transitory impact on the analyst coverage and reporting behavior of treated firms. Additionally, we can assess the validity of the parallel trends assumption required for our difference-in-differences approach in Section 3.5.4.

We examine the event window allowing the postevent window to extend one, two, and three periods after the merger. We re-estimate our baseline regression model, (1), but now assessing the mean change in coverage and financial reporting quality between treated and control samples using these longer post-event windows. We employ the most restrictive regression specification, using merger, industry, and firm fixed effects.

Table 5 shows the results. Panel A displays the dynamic effects of the mergers on coverage and Panel $\mathrm{B}$ the effects on financial reporting quality. The first column in each panel replicates the baseline result in Table 3. These results show that in the year around the merger, treated firms lose approximately one analyst and experience a coincident deterioration in financial reporting quality, on average, relative to control firms. ${ }^{18}$

Next, we expand the post-event window. We find that for the two years following the merger, on average, these effects persist in terms of magnitude and statistical significance. The average treatment effect in the FRQ regression decreases slightly from 0.025 to 0.022 when we consider a two-year post-event window. With a threeyear post-event window, the magnitude of the FRQ treatment effect declines slightly again to 0.018. The effect of the merger on coverage does not reverse two or three years out.

Taken together, these results indicate that there are no post-trends in the data and the effect of the merger on coverage is permanent for three years ahead. This finding mirrors (Hong and Kacperczyk, 2010), which also documents a permanent effect on coverage for these merger events. Consistent with a monitoring mechanism, we find a permanent impact on $F R Q$, although our estimated effect

\footnotetext{
18 Note that the discrepancy in the POST $\times$ TREATED coefficient estimate for the coverage regression is due the inclusion of these additional fixed effects. We include these fixed effects here (and not in Table 3 ). The $95 \%$ confidence interval for this estimated treatment effect includes, most importantly, -1 and also the previous estimate.
} 
Table 5

Dynamic effect of mergers on coverage and $F R Q$

This table reports results from the estimating the panel regression in (1) extending the post-merger window from one year to two and three years. Accordingly, the one-, two-, and three-period ahead values of COVERAGE and FRQ are used as the dependent variable in Panels A and B, respectively. POST is a variable that is equal to one for the post-merger period and zero for the pre-merger period. For each merger, we construct an indicator variable (TREATED) which is equal to one for each stock covered by both merging brokerage houses (treatment sample) and zero otherwise. FRQ is trimmed at the $95 \%$ level. The regressions include two-digit SIC industry, merger, and firm fixed effects. $t$-Values (in parentheses) are robust to clustering at the firm level. **** *** * Denote $1 \%, 5 \%$, and $10 \%$ statistical significance. All variables are defined in Appendix A.

\begin{tabular}{|c|c|c|c|}
\hline & COVERAGE $_{-1,+1}$ & $\operatorname{COVERAGE}_{-1,+2}$ & COVERAGE $_{-1,+3}$ \\
\hline POST & $\begin{array}{c}0.204^{* * * * *} \\
(8.40)\end{array}$ & $\begin{array}{c}-0.027 \\
(-0.79)\end{array}$ & $\begin{array}{c}-0.170^{* * * *} \\
(-4.34)\end{array}$ \\
\hline TREATED & $\begin{array}{l}2.369^{* * * * *} \\
(12.76)\end{array}$ & $\begin{array}{l}2.595^{* * * *} \\
(13.32)\end{array}$ & $\begin{array}{l}2.626^{* * * *} \\
(13.70)\end{array}$ \\
\hline$P O S T \times T R E A T E D$ & $\begin{array}{c}-0.870^{* * * *} \\
(-5.73)\end{array}$ & $\begin{array}{c}-0.994^{* * * *} \\
(-6.18)\end{array}$ & $\begin{array}{r}-1.041^{* * * *} \\
(-5.57)\end{array}$ \\
\hline $\begin{array}{l}\text { Merger fixed } \\
\text { effects }\end{array}$ & Yes & Yes & Yes \\
\hline $\begin{array}{l}\text { Industry fixed } \\
\text { effects }\end{array}$ & Yes & Yes & Yes \\
\hline $\begin{array}{l}\text { Firm fixed } \\
\text { effects }\end{array}$ & Yes & Yes & Yes \\
\hline $\begin{array}{l}\text { Number of } \\
\text { observations }\end{array}$ & 93,005 & 86,242 & 81,383 \\
\hline$R$-squared & 0.834 & 0.851 & 0.851 \\
\hline
\end{tabular}

Panel B: Dynamic effect on financial reporting quality

\begin{tabular}{|c|c|c|c|}
\hline & $F R Q_{-1,+1}$ & $F R Q_{-1,+2}$ & $F R Q_{-1,+3}$ \\
\hline POST & $\begin{array}{c}0.002 \\
(-0.12)\end{array}$ & $\begin{array}{l}-0.002 \\
(-0.74)\end{array}$ & $\begin{array}{l}0.001 \\
(0.45)\end{array}$ \\
\hline TREATED & $\begin{array}{c}-0.005 \\
(-0.765)\end{array}$ & $\begin{array}{c}-0.001 \\
(-0.14)\end{array}$ & $\begin{array}{l}-0.007 \\
(-1.10)\end{array}$ \\
\hline$P O S T \times T R E A T E D$ & $\begin{array}{l}0.025^{* * *} \\
(2.126)\end{array}$ & $\begin{array}{c}0.022^{* * *} \\
(2.53)\end{array}$ & $\begin{array}{r}0.018^{* * *} \\
(2.26)\end{array}$ \\
\hline $\begin{array}{l}\text { Merger fixed } \\
\text { effects }\end{array}$ & Yes & Yes & Yes \\
\hline $\begin{array}{l}\text { Industry fixed } \\
\text { effects }\end{array}$ & Yes & Yes & Yes \\
\hline $\begin{array}{l}\text { Firm fixed } \\
\text { effects }\end{array}$ & Yes & Yes & Yes \\
\hline $\begin{array}{l}\text { Number of } \\
\text { observations }\end{array}$ & 93,005 & 86,242 & 81,383 \\
\hline$R$-squared & 0.419 & 0.429 & 0.381 \\
\hline
\end{tabular}

attenuates slightly by the end of year $t+3$. However, as with every event study, we are cautious when interpreting these results as this longer post-event window may incorporate information that is not relevant for the mergers under consideration.

\subsection{Does access to market finance matter?}

This section investigates if the reporting behavior of firms experiencing the coverage shock varies with their need to access external finance.
When firms lose coverage they experience an increase in information asymmetry, loss of market value, and increase in cost of equity capital (Kelly and Ljungqvist, 2012). This leads to a reduction in external financing and investment, especially for firms that are financially constrained (e.g., Derrien and Kecskes, forthcoming). If the cost associated with the loss of coverage is sufficiently large, we might reasonably expect to see firms manage the shock to information asymmetry by improving the quality of financial reporting. Better reporting by management may act as a partial substitute to this loss of information or act to attract additional coverage (as in Anantharaman and Zhang, 2012). Naturally, we would expect offsetting efforts by management to be concentrated among firms that are actively seeking external funding, especially for equity-dependent firms that wish to actively signal their quality (Lang and Lundholm, 2000; Myers and Majluf, 1984).

To investigate this hypothesis, we examine the crosssection of firms. We conduct two tests to see if the treatment effect-the estimated positive coefficient-of analyst coverage on financial reporting quality is attenuated for firms with a need for external financing.

First, we consider firm growth. Growing firms may have a greater need to tap capital markets in the future. For these firms, the information production and dissemination role of analysts-improving stock price efficiency and promoting investor recognition-is vital. Thus, these managers may be more likely to compensate for the loss of coverage with better quality disclosure. ${ }^{19}$

We proxy firm growth with sales growth. We partition our treatment sample into two subsamples based on median sales growth ("High" versus "Low"). We present these results in columns 1 and 2 of Table 6 . The estimated treatment effect indicates that the decrease in financial reporting quality is concentrated among the lower sales growth subgroup. The point estimate for this subgroup is positive and statistically significant. For firms with high sales growth, the estimated treatment effect is not statistically distinguishable from zero. This finding is consistent with low growth firms - those firms less likely to rely on external funding-reducing the transparency of their reporting following the coverage shock, but the high growth firms did not. This suggests that, for growth firms, the information-related costs of management reducing disclosure exceed the benefits.

Next we examine equity issuers. Firms with greater dependence on the public equity market for capital are most likely to suffer from the loss of information production and monitoring associated with coverage. Consequently, we expect the reduction in financial reporting quality to be concentrated among non-equity issuers.

We classify firms as equity issuers following Fama and French (2008). We compute net equity issues as the ratio of split-adjusted shares that are outstanding at the end of fiscal year $t-1$ to the split-adjusted shares that are outstanding at the end of fiscal year $t-2$. We classify firms

\footnotetext{
${ }^{19}$ Anantharaman and Zhang (2012) show that these firms are more likely to provide public financial guidance in response to a loss of coverage in a standard OLS framework that does not address the endogeneity of coverage.
} 
Table 6

Does access to market finance matter?

This table reports results from the estimation of (1), with the sample split according to market financing characteristics of treated firms. For each of the two variables according to which we split our sample, we run our baseline specification for two subsamples. In the first two columns, the two subsamples each include all control firm-years plus the treated firm-years that have a higher sales growth (first column) or the treated firm-years that have a lower sales growth (second column) than the median treated firm-year. In columns 3 and 4, the two subsamples each include all control firm-years plus the treated firm-years that are classified as a net equity issuer (third column) or the treated firm-years that are not classified as a net equity issuer (fourth column). POST is a variable that is equal to one for the post-merger period and zero for the pre-merger period. For each merger, we construct an indicator variable (TREATED) which is equal to one for each stock covered by both merging brokerage houses (treatment sample) and zero otherwise. Regressions include two-digit SIC industry, merger, and firm fixed effects. $t$-Values (in parentheses) are robust to clustering at the firm level. ${ }^{* * * *},{ }^{* *},{ }^{*}$ Denote $1 \%, 5 \%$, and $10 \%$ statistical significance. All variables are defined in Appendix A.

\begin{tabular}{|c|c|c|c|c|}
\hline \multirow[b]{2}{*}{$F R Q$} & \multicolumn{2}{|c|}{ Sales growth } & \multicolumn{2}{|c|}{ Equity issuer? } \\
\hline & High & Low & Yes & No \\
\hline POST & $\begin{array}{c}0.002 \\
(0.793)\end{array}$ & $\begin{array}{c}0.001 \\
(0.807)\end{array}$ & $\begin{array}{c}0.001 \\
(0.728)\end{array}$ & $\begin{array}{c}0.002 \\
(0.732)\end{array}$ \\
\hline TREATED & $\begin{array}{c}0.005 \\
(0.592)\end{array}$ & $\begin{array}{l}-0.020^{* * *} \\
(-2.530)\end{array}$ & $\begin{array}{c}0.006 \\
(0.875)\end{array}$ & $\begin{array}{l}-0.029^{* * * *} \\
(-3.375)\end{array}$ \\
\hline$P O S T \times T R E A T E D$ & $\begin{array}{c}0.011 \\
(0.817)\end{array}$ & $\begin{array}{l}0.042^{\text {**k* }} \\
(3.105)\end{array}$ & $\begin{array}{c}0.010 \\
(0.857)\end{array}$ & $\begin{array}{c}0.016^{* * * *} \\
(3.698)\end{array}$ \\
\hline Merger fixed effects & Yes & Yes & Yes & Yes \\
\hline Industry fixed effects & Yes & Yes & Yes & Yes \\
\hline Firm fixed effects & Yes & Yes & Yes & Yes \\
\hline Number of observations & 91,870 & 91,870 & 92,329 & 92,329 \\
\hline$R$-squared & 0.420 & 0.420 & 0.421 & 0.422 \\
\hline
\end{tabular}

with a net equity issuance value greater than or equal to one as net equity issuers. We present these results in columns 3 and 4 of Table 6 . Consistent with external financing playing a role, we observe that non-equity issuers reduce the quality of reporting following the coverage shock. We do not observe any such behavior among equity issuers. ${ }^{20}$

Overall, our results indicate that access to market finance does matter. Our evidence supports the hypothesis that quality of financial reporting at firms with a greater dependence on external funding does not deteriorate following the loss of coverage. These results indicate that in addition to good corporate governance providing an effective substitute for analyst coverage (as a monitoring mechanism), the need to tap capital markets also disciplines management and preserves incentives for high-quality financial reporting.

\subsection{Robustness of average treatment effect}

This section conducts a number of tests to confirm the validity of our experiment and the robustness of our estimated average treatment effect in Section 3.1.

${ }^{20}$ We also find a similar pattern when we consider net cash from external financing activities (sale of common and preferred stock less cash dividends paid or from debt issuance/repayment) based on statement of cash flows data (as in Bradshaw, Richardson, and Sloan, 2006).

\subsubsection{Control variables in baseline regression}

Estimates from our baseline regression model (see Table 3) are unbiased provided the change in the mean financial reporting quality of the treatment sample across the merger date is not due to any other factor other than the merger leading to a loss of analyst coverage of these stocks. This is the exogeneity assumption of the natural experiment. We believe the coverage shocks are plausibly exogenous, as the merger-related departures of analysts is likely due to redundancy or culture clash. That being said, two potential concerns remain, the first of which is addressed here and the second in the next subsection.

The first concern is that our estimated partial effect may be capturing systematic differences in characteristics between the treatment and control groups. To tackle this issue we now augment our baseline regression with control variables, including size and performance which are known to vary systematically with the use of discretionary accruals. Our panel approach easily allows us to control for other potential sources of systematic differences across firms that are not picked up by fixed effects (i.e., time-varying firm-specific observables that correlate with financial reporting). To this end, we estimate (1) including the potential sources of heterogeneity defined in Section 2.5.

The results shown in Table 7 indicate that our baseline estimate of the effect of coverage on financial reporting is robust to controlling for a large set of time-varying observables. Both the impact of the mergers on coverage (column 1) and the magnitude and statistical significance of the estimated treatment effect are robust. If anything, the accuracy of our estimates improves.

The inclusion of additional covariates has a negligible effect on the estimated treatment effect, which is strong evidence that our coverage shock is exogenous and resulting adjustment in reporting behavior is not a result of omitted variables bias.

\subsubsection{Difference-in-differences matching estimator}

Another potential concern is that if treatment and control firms differ along observable dimensions, then they are likely to differ along unobservable dimensions. If this is the case, including control variables in a linear regression framework might not adequately control for unobservable heterogeneity between treatment and control samples, especially if there exist nonlinearities in the data (e.g., Roberts and Whited, in press).

To address this concern, we now implement a difference-in-differences matching estimator. We construct a control sample of firms that are matched to the treated firms along a set of relevant, observable characteristics measured in the year prior to merger. We first match on size, then size and performance, and then size, performance, and financial reporting quality, and finally we incorporate all remaining covariates.

We focus specifically on these three covariates for three reasons. First, the mergers in our sample involve large brokerage houses that tend to cover big stocks. Second, size and performance are known to vary systematically with the use of discretionary accruals. Third, we additionally match on the level of FRQ to address the 
Table 7

Robustness: average treatment effect with control variables.

This table reports results from the estimation of the pooled panel regression in (1) with additional control variables. For each merger, we consider a one-year window prior to the merger (pre-merger window) and a one-year window after the merger (post-merger window). The dependent variable is either COVERAGE or FRQ. FRQ is trimmed at the 95\% level. POST is a variable that is equal to one for the post-merger period and zero for the pre-merger period. For each merger, we construct an indicator variable (TREATED) which is equal to one for each stock covered by both merging brokerage houses (treatment sample) and zero otherwise. If indicated, the regressions include two-digit SIC industry, merger, or firm fixed effects. $t$-Values (in parentheses) are robust to clustering at the firm level. ${ }^{* * *},{ }^{* *},{ }^{*}$ Denote $1 \%, 5 \%$, and $10 \%$ statistical significance. All variables are defined in Appendix A.

\begin{tabular}{|c|c|c|c|c|c|}
\hline & COVERAGE & FRQ & FRQ & FRQ & FRQ \\
\hline \multirow[t]{2}{*}{ POST } & 0.097 & 0.004 & $0.012^{*}$ & $0.014^{*}$ & $0.016^{* * *}$ \\
\hline & $(0.163)$ & $(0.667)$ & $(2.073)$ & (1.889) & $(2.451)$ \\
\hline \multirow[t]{2}{*}{ TREATED } & $6.008^{* * * *}$ & $-0.019^{* * *}$ & $-0.013^{*}$ & -0.009 & $-0.008^{* * *}$ \\
\hline & (11.860) & $(-2.497)$ & $(-1.960)$ & $(-1.639)$ & $(-2.229)$ \\
\hline \multirow[t]{2}{*}{$P O S T \times T R E A T E D$} & $-1.171^{* *}$ & $0.030^{* * * *}$ & $0.025^{* * * *}$ & $0.023^{* * *}$ & $0.023^{* * *}$ \\
\hline & $(-2.205)$ & (3.818) & (3.204) & $(2.764)$ & $(2.940)$ \\
\hline \multirow[t]{2}{*}{ LNSIZE } & $4.033^{* * * *}$ & $0.004^{*}$ & -0.003 & -0.002 & $0.009^{* * *}$ \\
\hline & $(40.652)$ & $(2.022)$ & $(-1.248)$ & $(-0.900)$ & $(2.345)$ \\
\hline \multirow[t]{2}{*}{ RETANN } & $3.667^{* * * *}$ & $-0.106^{* * *}$ & $-0.109^{* * * *}$ & $-0.146^{* * * *}$ & $-0.085^{\text {*** }}$ \\
\hline & $(4.243)$ & $(-3.260)$ & $(-3.448)$ & $(-5.079)$ & $(-2.660)$ \\
\hline \multirow[t]{2}{*}{$L N B M$} & $1.322^{* * * *}$ & $-0.018^{* * * *}$ & $-0.023^{* * * k}$ & $-0.008^{* * *}$ & $-0.010^{\text {**** }}$ \\
\hline & $(12.284)$ & $(-6.914)$ & $(-8.820)$ & $(-2.851)$ & $(-3.333)$ \\
\hline \multirow[t]{2}{*}{ SIGMA } & $4.691^{* * * *}$ & $0.189^{* * * *}$ & $0.157^{* * * *}$ & $0.092^{* * * *}$ & $0.049^{* *}$ \\
\hline & $(4.472)$ & $(16.516)$ & (13.823) & $(9.757)$ & $(2.730)$ \\
\hline \multirow[t]{2}{*}{ VOLROE } & $0.018^{* * *}$ & 0.000 & 0.000 & 0.000 & -0.004 \\
\hline & $(2.956)$ & (1.338) & $(1.074)$ & $(1.414)$ & $(-0.066)$ \\
\hline \multirow[t]{2}{*}{ COVERAGE } & & 0.000 & $0.001^{*}$ & $0.001^{\text {** }}$ & 0.000 \\
\hline & & $(0.714)$ & $(1.959)$ & $(2.661)$ & $(0.706)$ \\
\hline Merger fixed effects & No & No & Yes & Yes & Yes \\
\hline Industry fixed effects & No & No & No & Yes & Yes \\
\hline Firm fixed effects & No & No & No & No & Yes \\
\hline Number of observations & 39,384 & 39,384 & 39,384 & 39,384 & 39,384 \\
\hline$R$-squared & 0.552 & 0.106 & 0.118 & 0.196 & 0.497 \\
\hline
\end{tabular}

potential concern that all firms (i.e., both treated and control) with better than average reporting quality are experiencing a deterioration in $F R Q$. This concern is relevant as, in the year prior to merger, the treatment sample has, on average, better quality financial reporting (lower $F R Q$ ) relative to the control sample (see Table 2).

We adopt a nearest-neighbor propensity score matching scheme, originally developed by Rosenbaum and Rubin (1983) and often used in our context (e.g., Balakrishnan, Billings, Kelly, and Ljungqvist, 2012; He and Tian, forthcoming). In a first step, we run a logit regression of an indicator variable that equals one if a particular firm-year is classified as treated (and zero otherwise) on our matching variables. This regression is estimated using a panel of 1,088 treatment and 18,604 candidate control pre-merger firm-years, which is the sample containing all control variables (see Appendix B). The estimated coefficients are used to predict probabilities of treatment (propensity scores), which are then used to perform a nearest-neighbor match. We perform the propensity score match with replacement using a standard tolerance ( 0.005 caliper) and allowing for up to three unique matches per treated firm. ${ }^{21}$

\footnotetext{
21 Since the number of candidate control firms exceeds the number of treated firms, we use multiple matches to improve the accuracy of our estimates.
}

Table 8 displays the results. Panel A shows the summary statistics for the treatment and (matched) control samples. The number of successful matches drops due a lack of eligible control firms as we include more covariates into the matching scheme. These summary statistics indicate that we achieve covariate balance among treatment and control samples along the dimensions we match on. Panel B shows the effect of the brokerage house mergers on coverage, verifying that the merger shock continues to have a meaningful impact on coverage using our matched sample. Panel $\mathrm{C}$ shows the matching estimator yields very similar estimates of the average treatment effect, in terms of economic and statistical significance. The results in Panels B and C hold, regardless of the set of matching covariates. ${ }^{22}$

Overall, these results indicate that the our baseline results are not driven by cross-sectional heterogeneity between treatment and control groups. In particular, we show that differences in size and performance between treatment and control samples do not drive our results.

\footnotetext{
${ }^{22}$ When matching on all covariates, the difference in initial analyst coverage is statistically significant. However, this difference is small in economic terms. Thus, we believe it is unlikely that the estimates are confounded by an omitted variable that is correlated with this difference in the levels of initial coverage between treated and control firms. The stability of our matching estimates, and additional evidence on the validity of the parallel trends assumption (see Section 3.5.4 below) and controlling for coverage in the linear framework support this claim.
} 
Table 8

Robustness: difference-in-differences matching estimator.

This table reports summary statistics and results of using a difference-in-differences matching estimator. The treatment sample consists of all stocks covered by two merging brokerage houses around the one-year merger window with valid matching variables. The control sample is the remainder of the Compustat universe with valid matching variables. Treated firms are matched using a nearest-neighbor logit propensity score match using a 0.005 caliper and matching up to three control firms. Panel A shows summary statistics for the treatment and matched control samples in the year prior to merger. $N$ and $M$ represent the number of treatment and matched control firms, respectively. Panel B estimates the effect of the brokerage house mergers on coverage for the matched sample. Panel C estimates the effect of the brokerage house mergers on FRQ. FRQ is trimmed at the 95\% level and $t$-values (in parentheses) are robust to clustering at the firm-level. ****, **, * Denote $1 \%, 5 \%$, and $10 \%$ statistical significance. All variables are defined in Appendix A.

\begin{tabular}{|c|c|c|c|c|c|c|c|c|}
\hline \multirow[t]{2}{*}{ Variable } & \multicolumn{3}{|c|}{ Treated firms } & \multicolumn{3}{|c|}{ Matched control firms } & \multirow{2}{*}{$\begin{array}{l}\text { Difference } \\
\text { in means }\end{array}$} & \multirow[b]{2}{*}{$t$-Stat. } \\
\hline & Mean & Std. & Med. & Mean & Std. & Med. & & \\
\hline \multicolumn{9}{|c|}{ (i) Matching on LNSIZE ( $N=999 ; M=2,978)$} \\
\hline FRQ & 0.169 & 0.608 & 0.045 & 0.199 & 0.607 & 0.052 & -0.030 & $(-1.35)$ \\
\hline LNSIZE & 8.590 & 1.535 & 8.546 & 8.571 & 1.517 & 8.528 & 0.196 & $(0.35)$ \\
\hline RETANN & 0.009 & 0.036 & 0.012 & 0.009 & 0.037 & 0.010 & 0.001 & $(0.40)$ \\
\hline COVERAGE & 24.44 & 10.39 & 23 & 20.00 & 10.29 & 19 & 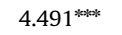 & $(11.82)$ \\
\hline LNBM & -1.111 & 0.927 & -0.993 & -1.276 & 0.887 & -1.210 & $0.164^{* * * *}$ & $(4.87)$ \\
\hline SIGMA & 0.427 & 0.227 & 0.379 & 0.453 & 0.231 & 0.406 & $-0.026^{\text {**** }}$ & $(-3.13)$ \\
\hline VOLROE & 0.406 & 1.864 & 0.102 & 0.508 & 2.442 & 0.103 & -0.103 & $(-1.38)$ \\
\hline \multicolumn{9}{|c|}{ (ii) Matching on LNSIZE/RETANN $(N=999 ; M=2,973)$} \\
\hline FRQ & 0.170 & 0.608 & 0.045 & 0.187 & 0.533 & 0.055 & 0.016 & $(0.79)$ \\
\hline LNSIZE & 8.603 & 1.551 & 8.548 & 8.582 & 1.532 & 8.541 & 0.217 & $(0.38)$ \\
\hline RETANN & 0.009 & 0.036 & 0.012 & 0.010 & 0.038 & 0.011 & -0.001 & $(-0.50)$ \\
\hline COVERAGE & 24.49 & 10.40 & 23 & 19.915 & 10.131 & 19 & 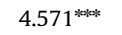 & $(12.10)$ \\
\hline$L N B M$ & -1.115 & 0.928 & -0.997 & -1.270 & 0.872 & -1.199 & $0.154^{* * * * *}$ & $(4.60)$ \\
\hline SIGMA & 0.427 & 0.227 & 0.381 & 0.465 & 0.231 & 0.418 & 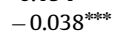 & $(-4.55)$ \\
\hline VOLROE & 0.405 & 1.862 & 0.102 & 0.440 & 1.934 & 0.098 & -0.035 & $(-0.51)$ \\
\hline \multicolumn{9}{|c|}{ (iii) Matching on LNSIZE/RETANN/FRQ $(N=996 ; M=2,971)$} \\
\hline FRQ & 0.169 & 0.608 & 0.045 & 0.168 & 0.431 & 0.056 & 0.001 & $(0.04)$ \\
\hline LNSIZE & 8.590 & 1.535 & 8.546 & 8.577 & 1.526 & 8.530 & 0.013 & $(0.25)$ \\
\hline RETANN & 0.009 & 0.036 & 0.012 & 0.010 & 0.042 & 0.011 & -0.001 & $(-0.52)$ \\
\hline COVERAGE & 24.44 & 10.39 & 23 & 20.089 & 10.280 & 19 & 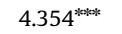 & $(11.48)$ \\
\hline LNBM & -1.111 & 0.927 & -0.993 & -1.262 & 0.873 & -1.175 & $0.151^{* * * *}$ & $(4.48)$ \\
\hline SIGMA & 0.427 & 0.227 & 0.379 & 0.453 & 0.218 & 0.416 & $-0.447^{\text {***k }}$ & $(-3.14)$ \\
\hline VOLROE & 0.406 & 1.864 & 0.102 & 0.419 & 1.961 & 0.102 & -0.0135 & $(-0.19)$ \\
\hline \multicolumn{9}{|c|}{ (iv) Matching on all covariates ( $N=944 ; M=2,731)$} \\
\hline FRQ & 0.161 & 0.589 & 0.042 & 0.195 & 0.620 & 0.049 & -0.034 & $(-1.51)$ \\
\hline LNSIZE & 8.610 & 1.553 & 8.550 & 8.638 & 1.562 & 8.666 & -0.028 & $(0.48)$ \\
\hline RETANN & 0.010 & 0.035 & 0.012 & 0.010 & 0.036 & 0.011 & 0.000 & $(0.16)$ \\
\hline COVERAGE & 24.047 & 10.018 & 23 & 21.097 & 10.402 & 20 & $2.95^{* * * *}$ & $(-7.72)$ \\
\hline$L N B M$ & -1.106 & 0.912 & -0.997 & -1.153 & 0.893 & -1.070 & 0.048 & (1.39) \\
\hline SIGMA & 0.423 & 0.226 & 0.375 & 0.436 & 0.215 & 0.390 & -0.013 & $(-1.51)$ \\
\hline VOLROE & 0.365 & 1.836 & 0.097 & 0.275 & 0.997 & 0.093 & 0.089 & (1.43) \\
\hline
\end{tabular}

Panel B: Change in COVERAGE: DiD matching estimator

COVERAGE

LNSIZE-matched

(Standard error)

LNSIZE/RETANN-matched

(Standard error)

LNSIZE/RETANN/FRQ-matched

(Standard error)

LNSIZE/.../VOLROE-matched

(Standard error)

\section{COVERAGE}

$-1.023^{* * * * k}$
$(0.089)$
$-0.900^{* * * *}$
$(0.089)$
$-1.005^{* * * k}$
$(0.088)$
$-0.783^{* * * k}$
$(0.092)$

Panel C: Change in FRQ: DiD matching estimator

FRQ

LNSIZE-matched

(Standard error)

LNSIZE/RETANN-matched

(Standard error)

LNSIZE/RETANN/FRQ-matched

(Standard error)

LNSIZE / .../VOLROE-matched

(Standard error)

$0.042^{* * *}$

(0.018)

$0.032^{* * *}$

(0.015)

0.029*

(0.016)

$0.039 *$

(0.023) 
Additionally matching on FRQ directly addresses the concern that treated firms have high-quality absolute discretionary accruals and all such firms in the sample

\section{Table 9}

Robustness: alternative measures for $F R Q$

This table reports results from the estimation of the pooled panel regression in (1). For brevity, we only report the estimated coefficient on the POST $\times$ TREATED interaction. The dependent variables are listed in the first column and are alternative measures of $F R Q$. For each merger, we consider a one-year window prior to merger (pre-merger window) and a one-year window after the merger (post-merger window). POST is a variable that is equal to one for the post-merger period and zero for the pre-merger period. For each merger, we construct an indicator variable (TREATED) which is equal to one for each stock covered by both merging brokerage houses (treatment sample) and zero otherwise. All regressions include two-digit SIC industry, merger, and firm fixed effects. $t$-Values (in parentheses) are robust to clustering at the firm level. *** *** * Denote $1 \%$, $5 \%$, and $10 \%$ statistical significance. All variables are defined in Appendix A.

\begin{tabular}{lcc}
\hline Dependent variable & POST $\times$ TREATED & $t$-Value \\
\hline FOG & 0.204 & $2.78^{\text {*** }}$ \\
NWORDS & 2479.239 & $2.18^{*}$ \\
CA & 0.005 & $3.07^{\text {***** }}$ \\
CA (cash flow) & 0.004 & $2.25^{\text {*** }}$ \\
CA (exc. depr.) & 0.006 & $2.90^{\text {**** }}$ \\
\hline
\end{tabular}

(i.e., both treated and control) follow a similar pattern of decline. Indeed, we find such a pattern of decline only among treated firms and only after the coverage shock takes place. Our estimates remain very similar in magnitude and statistical significance when we match on all covariates, which provides further evidence that the natural experiment is working.

\subsubsection{Alternative measures of financial reporting quality}

Next, we verify that our results are robust to several alternative measures of financial reporting quality (FRQ). These results are presented in Table 9.

The first alternative measure is the Fog index (FOG), which was first introduced to academic finance and accounting research by $\mathrm{Li}$ (2008). The construction of these variables is described in detail in Section 2.3. The Fog index can be interpreted as the number of years that a reader has to be of age to understand a certain text after a single reading. The higher the Fog index, the more complicated the text is to understand. In our setting, a higher Fog index would indicate a more convoluted annual report (a decrease in financial reporting quality) and a lower Fog index would indicate a more succinct

\section{Table 10}

Validity of the natural experiment: placebo regressions.

This table reports results from estimating the panel regression in (1). The dependent variable is FRQ. FRQ is trimmed at the 95\% level. In Panel A, we shift the one-year window prior/after the merger window by one year into the future. In Panel B, we shift the one-year window prior/after the merger window by one year into the past. POST is a variable that is equal to one for the (shifted) post-merger period and zero for the (shifted) pre-merger period. For each merger, we construct an indicator variable (TREATED) which is equal to one for each stock covered by both merging brokerage houses (treatment sample) and zero otherwise. If indicated, the regressions include two-digit SIC industry, merger, or firm fixed effects. $t$-Values (in parentheses) are robust to clustering at the firm level. ***, ***, * Denote $1 \%, 5 \%$, and $10 \%$ statistical significance. All variables are defined in Appendix A.

\begin{tabular}{|c|c|c|c|c|}
\hline Panel A: Event date shifted & FRQ & $F R Q$ & FRQ & FRQ \\
\hline POST & $\begin{array}{l}0.011^{* * * * *} \\
(0.000)\end{array}$ & $\begin{array}{l}0.017^{\text {***k }} \\
(0.000)\end{array}$ & $\begin{array}{l}0.017^{* * * * *} \\
(0.000)\end{array}$ & $\begin{array}{l}0.019^{* * * * *} \\
(0.000)\end{array}$ \\
\hline TREATED & $\begin{array}{c}-0.055^{* * * * *} \\
(0.000)\end{array}$ & $\begin{array}{c}-0.038^{\text {*k*k* }} \\
(0.000)\end{array}$ & $\begin{array}{l}-0.003 \\
(0.708)\end{array}$ & $\begin{array}{c}0.010 \\
(0.197)\end{array}$ \\
\hline$P O S T \times T R E A T E D$ & $\begin{array}{l}-0.012 \\
(0.300)\end{array}$ & $\begin{array}{l}-0.015 \\
(0.208)\end{array}$ & $\begin{array}{l}-0.015 \\
(0.208)\end{array}$ & $\begin{array}{r}-0.017 \\
(0.171)\end{array}$ \\
\hline $\begin{array}{l}\text { Merger fixed effects } \\
\text { Industry fixed effects } \\
\text { Firm fixed effects }\end{array}$ & $\begin{array}{l}\text { No } \\
\text { No } \\
\text { No }\end{array}$ & $\begin{array}{l}\text { Yes } \\
\text { No } \\
\text { No }\end{array}$ & $\begin{array}{l}\text { Yes } \\
\text { Yes } \\
\text { No }\end{array}$ & $\begin{array}{l}\text { Yes } \\
\text { Yes } \\
\text { Yes }\end{array}$ \\
\hline $\begin{array}{l}\text { Number of observations } \\
R \text {-squared }\end{array}$ & $\begin{array}{c}86,852 \\
0.001\end{array}$ & $\begin{array}{c}86,852 \\
0.027\end{array}$ & $\begin{array}{c}86,852 \\
0.200\end{array}$ & $\begin{array}{r}86,852 \\
0.389\end{array}$ \\
\hline \multicolumn{5}{|c|}{ Panel B: Event date shifted one year backward } \\
\hline POST & $0.032^{* * * * *}$ & $0.035^{\text {****k }}$ & $0.035^{\text {**k* }}$ & $0.030^{* * * *}$ \\
\hline TREATED & $\begin{array}{c}-0.050^{* * * * * *} \\
(0.000)\end{array}$ & $\begin{array}{c}-0.043^{* * * * *} \\
(0.000)\end{array}$ & $\begin{array}{c}-0.016^{* * * *} \\
(0.004)\end{array}$ & $\begin{array}{l}-0.002 \\
(0.781)\end{array}$ \\
\hline$P O S T \times$ TREATED & $\begin{array}{c}0.002 \\
(0.825)\end{array}$ & $\begin{array}{l}-0.001 \\
(0.870)\end{array}$ & $\begin{array}{l}-0.007 \\
(0.341)\end{array}$ & $\begin{array}{r}-0.006 \\
(0.435)\end{array}$ \\
\hline Merger fixed effects & No & Yes & Yes & Yes \\
\hline Industry fixed effects & No & No & Yes & Yes \\
\hline Firm fixed effects & No & No & No & Yes \\
\hline Number of observations & 89,027 & 89,027 & 89,027 & 89,027 \\
\hline$R$-squared & 0.005 & 0.040 & 0.211 & 0.452 \\
\hline
\end{tabular}


annual report (an increase in quality). The second measure we use is the number of words in the annual report. The common interpretation is that a longer report is harder to read and corresponds to less effective communication by management. In our context, a higher number of words indicates a decrease in financial reporting quality and a lower number of words indicates an increase in financial reporting quality.

Following Sloan (1996), we also use three additional non-regression-based measures, which we broadly term as current accruals (CA). Each of these measures use accounting data, but do not rely on a regression framework to calculate abnormal accruals. In both cases, a higher number for the measure indicates more accruals and thus lower financial reporting quality.

For brevity, we report only the estimated ATE, $\beta_{3}$, obtained from estimating (1) for each of these alternative measures of financial reporting quality. They show that our main finding presented earlier is robust across these different measures. Following a decrease in analyst coverage, companies' annual reports require a reader to be older to understand it (higher FOG) and companies' annual reports are longer (higher NWORDS). Additionally, for each of the current accruals measures, firms' total accruals increase, indicating a bigger wedge between a firm's cash flows and earnings, making it harder for an investor to discern true performance. We thus corroborate our main result that companies report accounting numbers of lower quality following an exogenous loss of coverage.

\subsubsection{Validity of natural experiment}

The validity of our DiD approach hinges on the parallel trends assumption. This requires that treated and control firms have similar financial reporting behavior prior to the merger. We confirm the validity of our empirical design by conducting a falsification analysis and also revisiting the results on dynamics from Section 3.3.

Table 10 presents these results. We repeat our analysis from Table 3, but mechanically shift each event date by a year forward (Panel A) or backward (Panel B). For instance, for Merger 1, we shift the event one year forward to $12 / 31 / 1993$ in Panel A of Table 10 and a year later to $12 / 31 / 1995$ in Panel B. If our result that firms react to the exogenous loss of coverage holds (and their behavior is not simply the result of an overall trend), we would expect to find insignificant estimated ATE coefficients in both of these exercises.

The results presented in both panels of Table 10 confirm this interpretation. Regardless of specification and regardless of whether we artificially shift the merger event dates by one year forward or one year backward, we find insignificant estimated ATEs across all specifications. This indicates that the deterioration in financial reporting quality among the treatment sample takes place only around our event dates.

Table 5 examines the dynamic effects of the merger and provides additional evidence consistent with this interpretation. In particular, by extending the post-event window to two and three years after the event date, two patterns emerge. First, the effect of the merger on
Table 11

Validity of the natural experiment: inter-merger evidence.

This table reports results from the estimation of the pooled panel regression in (1) on a merger-by-merger basis. For each merger, we consider a one-year window prior to the merger (pre-merger window) and a one-year window after the merger (post-merger window). The dependent variable is FRQ. FRQ is trimmed at the 95\% level. POST is a variable that is equal to one for the post-merger period and zero for the pre-merger period. For each merger, we construct an indicator variable (TREATED) which is equal to one for each stock covered by both merging brokerage houses (treatment sample) and zero otherwise. All regressions for individual mergers include two-digit SIC industry fixed-effects. The last regression includes two-digit SIC industry, merger, and firm fixed effects. $t$-Values (in parentheses) are robust to clustering at the firm level. ${ }^{* * * *}, * *, *$ Denote $1 \%, 5 \%$, and 10\% statistical significance. Merger numbers are identified in Table 1 and all other variables are defined in Appendix A.

\begin{tabular}{lcc}
\hline Merger & POST $\times$ TREATED & $t$-Value \\
\hline 1 & 0.016 & $1.98^{*}$ \\
2 & 0.014 & 1.09 \\
3 & 0.002 & 0.20 \\
4 & -0.057 & -1.33 \\
5 & 0.049 & 0.57 \\
6 & -0.017 & 1.25 \\
7 & -0.104 & $-1.80^{*}$ \\
8 & 0.015 & 0.41 \\
9 & 0.039 & $1.94^{*}$ \\
10 & 0.043 & $1.66^{*}$ \\
11 & 0.085 & 1.25 \\
12 & 0.264 & $1.87^{*}$ \\
13 & -0.164 & -0.89 \\
exc. $1,9,10,12$ & 0.026 & $2.17^{* *}$ \\
\hline
\end{tabular}

coverage and $F R Q$ for the treatment sample lasts for three years. Second, these effects occur only around the year of the merger, i.e., there is no post-trend.

Collectively, this evidence supports the parallel trends assumption by showing that the deterioration in reporting quality for the treated sample is not due to some trend either in the pre- or the post-period. Thus, we directly address the concern that there may be some reversion to the mean among treated firms, since we believe it is unlikely that mean reversion would happen only in the year of the merger and not in the years before or after.

In our next robustness test, we address the concern that our results may be driven by a time-series event coincident with one merger and the group of firms "treated" in that merger. In our baseline specification, we pool together all 13 mergers and run a single crosssectional regression. As we have shown in Table 1 , the number of treated firms is different across mergers. This might lead to a concern that our results are driven by one of the bigger mergers, i.e., one event only. To mitigate this concern, we re-estimate our baseline specification for each individual merger.

These results are presented in Table 11 . We report the estimated ATE coefficient only. As can be seen from the coefficients, the majority of stand-alone mergers have a positive DiD coefficient, which is statistically significant in four cases (mergers $1,9,10$, and 12). Three mergers have a negative estimated coefficient, which is significant in one case (merger 7). The fact that most mergers on their own have a positive coefficient goes some way towards 
Table 12

Analyst coverage and financial reporting: OLS estimation.

This table reports results from panel regressions of financial reporting quality on analyst coverage and control variables that do not account for the endogeneity of analyst coverage. The dependent variable is FRQ. FRQ is trimmed at the 95\% level. If indicated, the regressions include two-digit SIC industry, year, or firm fixed effects. $t$-Values (in parentheses) are robust to clustering at the industry level. ****, *** Denote $1 \%, 5 \%$, and $10 \%$ statistical significance. All variables are defined in Appendix A.

\begin{tabular}{|c|c|c|c|c|}
\hline & FRQ & FRQ & $F R Q$ & FRQ \\
\hline COVERAGE & $\begin{array}{c}0.0004 \\
(0.583)\end{array}$ & $\begin{array}{c}0.0016^{* * * *} \\
(2.389)\end{array}$ & $\begin{array}{c}0.0012^{* * *} \\
(2.813)\end{array}$ & $\begin{array}{l}0.0007 \\
(0.996)\end{array}$ \\
\hline LNSIZE & $\begin{array}{l}0.0042 \\
(0.994)\end{array}$ & $\begin{array}{l}-0.0095^{* *} \\
(-2.001)\end{array}$ & $\begin{array}{c}-0.0092^{* * *} \\
(-3.418)\end{array}$ & $\begin{array}{l}-0.0106^{*} \\
(-1.814)\end{array}$ \\
\hline RETANN & $\begin{array}{c}-0.0837 \\
(-1.549)\end{array}$ & $\begin{array}{l}-0.1093^{* *} \\
(-2.145)\end{array}$ & $\begin{array}{c}-0.1721^{* * * *} \\
(-3.304)\end{array}$ & $\begin{array}{l}-0.1387^{*} \\
(-1.816)\end{array}$ \\
\hline$L N B M$ & $\begin{array}{c}-0.0206^{* * * *} \\
(-4.108)\end{array}$ & $\begin{array}{c}-0.0284^{* * * *} \\
(-6.041)\end{array}$ & $\begin{array}{c}-0.0124^{* * * *} \\
(-3.614)\end{array}$ & $\begin{array}{c}-0.0172^{* * *} \\
(-2.416)\end{array}$ \\
\hline SIGMA & $\begin{array}{c}0.1815^{\text {**k* }} \\
(9.956)\end{array}$ & $\begin{array}{c}0.1191^{* * * *} \\
(3.835)\end{array}$ & $\begin{array}{c}0.0355^{* * k} \\
(2.054)\end{array}$ & $\begin{array}{l}-0.0138 \\
(-0.374)\end{array}$ \\
\hline VOLROE & $\begin{array}{c}0.0010^{* * * * k} \\
(2.709)\end{array}$ & $\begin{array}{c}0.0008^{* *} \\
(2.364)\end{array}$ & $\begin{array}{c}0.0009 * * \\
(2.297)\end{array}$ & $\begin{array}{r}0.2831^{\text {***** }} \\
(6.004)\end{array}$ \\
\hline Year fixed Effects & No & Yes & Yes & Yes \\
\hline Industry fixed effects & No & No & Yes & Yes \\
\hline Firm fixed effects & No & No & No & Yes \\
\hline Number of observations & 16,913 & 16,913 & 16,913 & 16,913 \\
\hline$R$-squared & 0.0763 & 0.1195 & 0.1878 & 0.2724 \\
\hline
\end{tabular}

mitigating concerns that a single merger is driving our results. To further alleviate this concern, we rerun the analysis and exclude all mergers that have a significantly positive DiD coefficient when estimated individually. The result of this specification is presented in the last line in Table 11 . When we exclude these mergers (i.e., mergers 1 , 9,10 , and 12 ), the estimated ATE is still positive and statistically significant $\left(\beta_{3}=0.026, t=2.17\right)$. The magnitude and significance of the estimated coefficient is quantitatively very similar to our baseline result. This demonstrates that our main result presented earlier is not driven by a small number of mergers or one big merger.

Our empirical strategy has the requirement that treated firms must be covered by both merging brokerage houses in the year prior to merger. In a final test, we consider an alternative definition of the treatment indicator. We re-examine our baseline results by focusing on stocks that are covered by only one of the merging brokerage houses (but not both) in the year prior to the merger. Using this alternative definition of the treatment indicator, ${ }^{23}$ in unreported results, we do not find that these treated stocks experience a meaningful loss of coverage nor adjustment in FRQ following the merger. The point estimate of the effect of the mergers on treated firms' coverage is -0.070 (not statistically significant) and the estimated effect on FRQ is also negligible. ${ }^{24,25}$

\footnotetext{
${ }^{23}$ We exclude firms covered by both merging houses from the sample.

${ }^{24}$ Hong and Kacperczyk (2010) report similar results.

${ }^{25}$ This finding presents an opportunity to examine the quality of our control group used in Table 3. We redefine our control sample to be the set of stocks covered by only one of the two merging brokerage houses. Using this alternative control group does not change the nature of our results. These results are unreported and available upon request.
}

\subsection{Results from OLS estimation}

We conclude our empirical analysis by estimating pooled OLS regressions of our measure of financial reporting quality, $F R Q$ on analyst coverage and the set of control variables detailed in Section 2.5. Specifically, we estimate

$F R Q_{i t}=\alpha_{t}+\alpha_{j}+\alpha_{i}+\beta C O V E R A G E_{i t}+\gamma^{\prime} X_{i t}+\epsilon_{i t}$,

where, depending on the specification we use, we also include year fixed effects $\left(\alpha_{t}\right)$, two-digit SIC industry fixed effects $\left(\alpha_{j}\right)$, and firm fixed effects $\left(\alpha_{i}\right)$. To be comparable with the results from our natural experiment, we restrict our sample to the time period from 1994 until 2005.

The OLS regression results are presented in Table $12 .^{26}$ We present the results without any fixed effects, and then gradually introduce time fixed effects, industry fixed effects, and firm fixed effects. The coefficient on COVER$A G E$ is very small and ranges from 0.0004 to 0.0016 , an order of magnitude lower than the estimates from our experiment. To further compare with our experimental evidence, these estimates indicate that a unit drop in stock-level coverage is associated with higher abnormal accruals and thus lower financial reporting quality. However, our results also reveal that this effect is small in magnitude and the precision of these estimates depends on the fixed-effects specification we use.

As we have previously discussed, these OLS results are hard to interpret due to the endogenous relationship

\footnotetext{
${ }^{26}$ We note that the sample of the regressions estimated in Table 12 is smaller than the sample of the regressions estimated in Table 7. This is due to the fact that in the sample used in Table 12 , every firm-year appears once. In Table 7, however, a particular firm-year can enter the sample multiple times, e.g., when a firm-year acts as a control firm-year for multiple mergers occurring close to each other.
} 
between analyst coverage and financial reporting quality. This methodology treats both exogenous (e.g., due to brokerage house mergers) and endogenous changes in analyst coverage uniformly. In contrast, the experimental design we adopt zones in on a specificalthough pervasive in both the cross-section and timeseries-set of exogenous reductions in coverage. We use these events to identify an economically meaningful and statistically significant effect, which is stable across a number of specifications and survives numerous robustness tests.

\section{Conclusion}

We examine how changes in analyst coverage affect the quality of financial information generated and provided by the firm. We use a sample of 13 U.S. brokerage house mergers with overlapping coverage universes occurring between 1994 and 2005 as a source of exogenous variation in monitoring and information production about a firm. We demonstrate that merging houses with overlapping coverage reduce securities analyst coverage in the year following the merger. Using this variation, we attempt to isolate the causal impact of a reduction in coverage on firms' financial reporting quality. Using a difference-in-differences methodology, we demonstrate that treated firms increase the use of abnormal accruals in their accounting statements in the year following the merger. Cross-sectional analysis indicates that this effect is concentrated among firms with low initial coverage, firms with weak shareholder rights (consistent with a substitution effect between governance and analyst coverage), and firms that are least likely to access equity markets. We also document that the results of simple OLS regressions that do not take into account the potential endogenous relation between coverage and disclosure yield economically small and statistically insignificant results that are unstable with respect to the regression specification employed.

Our findings shed light on the interaction between corporate governance, financial constraints, and corporate information disclosure policy. The behavior on the part of growth firms and equity issuers is consistent with recent evidence presented by Derrien and Kecskes (forthcoming), who show that following a loss of coverage, such firms lose access to external finance and as a consequence reduce investment. Our findings suggest that while such firms improve the quality of the financial reporting, they are unable to fully offset the loss of information. On the other hand, among poorly governed firms, the reduction in financial reporting quality is consistent with managerial misreporting as in Kedia and Philippon (2009). In their model, these firms losing monitors may be interpreted as a reduction in the probability of detecting managerial misbehavior by external monitors, which ultimately leads to excessive investment and hiring by unproductive firms.

Investigating the interaction between corporate governance and disclosure and the implications for the real economy remains an exciting area for future research.

\section{Appendix A. Variable definitions}

This appendix presents the definitions for the variables used throughout the paper.

\begin{tabular}{|c|c|}
\hline \multicolumn{2}{|c|}{ Financial reporting quality variables } \\
\hline Variable & Definition \\
\hline FRQ & $\begin{array}{l}\text { Absolute abnormal accruals computed as the } \\
\text { difference between a company's total } \\
\text { accruals and its nondiscretionary accruals. }\end{array}$ \\
\hline$C A$ & $\begin{array}{l}\text { Non-regression current accruals measure as in Sloan } \\
(1996)\end{array}$ \\
\hline $\begin{array}{l}\text { CA (cash } \\
\text { flow) }\end{array}$ & $\begin{array}{l}\text { Current accruals measure as in Hribar and Collins } \\
(2002)\end{array}$ \\
\hline $\begin{array}{l}C A(\text { exc. } \\
\text { depr.) }\end{array}$ & $\begin{array}{l}\text { Current accruals measure excluding depreciation as } \\
\text { in Barton and Simko (2002) }\end{array}$ \\
\hline FOG & Readability of SEC 10-K filing as in Li (2008) \\
\hline NWORDS & Number of words in SEC $10-\mathrm{K}$ filing \\
\hline \multicolumn{2}{|c|}{ Control variables } \\
\hline Variable & Definition \\
\hline COVERAGE & $\begin{array}{l}\text { Number of analysts in } \mathrm{I} / \mathrm{B} / \mathrm{E} / \mathrm{S} \text { covering stock in } \\
\text { current year }\end{array}$ \\
\hline LNSIZE & $\begin{array}{l}\text { Natural logarithm of market capitalization (price } \\
\text { times shares outstanding) }\end{array}$ \\
\hline RETANN & Average monthly return of a stock in current year \\
\hline$L N B M$ & $\begin{array}{l}\text { Natural logarithm of a firm's book value divided by } \\
\text { its market capitalization }\end{array}$ \\
\hline SIGMA & Variance of daily (simple, raw) returns \\
\hline \multirow[t]{2}{*}{ VOLROE } & $\begin{array}{l}\text { Variance of the residuals from the } A R(1) \text { model of } \\
\text { each stock's return on equity (ROE). }\end{array}$ \\
\hline & $\begin{array}{l}\text { The } \operatorname{AR}(1) \text { is estimated using a ten-year series of valid } \\
\text { annual ROE, where ROE } \\
\text { is calculated as the ratio of earnings over the book } \\
\text { value of equity. }\end{array}$ \\
\hline$N E I$ & $\begin{array}{l}\text { Ratio of the split-adjusted shares outstanding at the } \\
\text { end of fiscal year } t-1 \\
\text { to the split-adjusted shares outstanding at the end of } \\
\text { fiscal year } t-2 \text {, } \\
\text { as in Armstrong, Balakrishnan, and Cohen (2012) }\end{array}$ \\
\hline SALESGR & Year-to-year percentage growth in sales \\
\hline \multicolumn{2}{|c|}{ Corporate governance variables } \\
\hline Variable & Definition \\
\hline G-INDEX & $\begin{array}{l}\text { Index of } 24 \text { shareholder rights introduced by } \\
\text { Gompers, Ishii, and Metrick (2003) }\end{array}$ \\
\hline$E-I N D E X$ & $\begin{array}{l}\text { Index of six shareholder rights introduced by } \\
\text { Bebchuk, Cohen, and Ferrell (2009) }\end{array}$ \\
\hline DUAL & $\begin{array}{l}\text { Indicator for whether a dual-class share structure is } \\
\text { in place }\end{array}$ \\
\hline$C C-D U A L$ & $\begin{array}{l}\text { Indicator for whether CEO is also chairman of the } \\
\text { board }\end{array}$ \\
\hline
\end{tabular}

\section{Appendix B. Sample construction}

This table reports samples used in the main analyses in Tables 3-7, partitioned into treatment and control groups. The sample begins with 144,943 firm-year observations consisting of all publicly traded US firms that have an earnings forecast in the 365-day window around every brokerage house merger date. For other samples, we begin with 93,005 firm-year observations that make up the sample used in Table 3. All variables are defined in Appendix A. 


\begin{tabular}{|c|c|c|c|c|}
\hline & \multicolumn{2}{|c|}{ Treated firms } & \multicolumn{2}{|c|}{ Control firms } \\
\hline & Firms & Firm-years & Firms & Firm-years \\
\hline \multicolumn{5}{|c|}{ Sample used in Table 3: } \\
\hline Eligible observations & 1,938 & 3,876 & 70,534 & 141,067 \\
\hline \multicolumn{5}{|l|}{ Observations with valid: } \\
\hline link to Compustat & 1,428 & 2,856 & 53,813 & 107,626 \\
\hline$F R Q$ & 1,204 & 2,408 & 47,748 & 95,496 \\
\hline 95\% Trimming & 1,179 & 2,358 & 45,324 & 90,647 \\
\hline Final sample size & 1,179 & 2,358 & 45,324 & 90,647 \\
\hline \multicolumn{5}{|c|}{ Samples used in Table 4: } \\
\hline Eligible observations & 1,179 & 2,358 & 45,324 & 90,647 \\
\hline \multicolumn{5}{|c|}{ Observations with valid: } \\
\hline G-INDEX & 671 & 1,342 & 9,941 & 19,881 \\
\hline E-INDEX & 671 & 1,342 & 9,941 & 19,881 \\
\hline$C C-D U A L$ & 604 & 1,208 & 9,896 & 19,791 \\
\hline$D U A L$ & 671 & 1,342 & 9,941 & 19,881 \\
\hline \multicolumn{5}{|c|}{ Samples used in Table 6: } \\
\hline Eligible observations & 1,179 & 2,358 & 45,324 & 90,647 \\
\hline \multicolumn{5}{|l|}{ Observations with valid: } \\
\hline SALES & 1,179 & 2,358 & 44,756 & 89,512 \\
\hline$N E I$ & 1,134 & 2,268 & 45,031 & 90,061 \\
\hline \multicolumn{5}{|l|}{ Sample used in Table 7: } \\
\hline Eligible observations & 1,179 & 2,358 & 45,324 & 90,647 \\
\hline \multicolumn{5}{|l|}{ Observations with valid: } \\
\hline RETANN & 1,143 & 2,286 & 34,325 & 68,650 \\
\hline SIGMA & 1,141 & 2,282 & 34,082 & 68,164 \\
\hline LNSIZE & 1,140 & 2,280 & 34,079 & 68,158 \\
\hline LNBM & 1,140 & 2,280 & 34,079 & 68,158 \\
\hline VOLROE & 1,088 & 2,176 & 18,604 & 37,208 \\
\hline COVERAGE & 1,088 & 2,176 & 18,604 & 37,208 \\
\hline Final sample size & 1,088 & 2,176 & 18,604 & 37,208 \\
\hline
\end{tabular}

\section{References}

Anantharaman, D., Zhang, Y., 2012. Cover me: Managers' responses to changes in analyst coverage in the post-regulation FD period. Accounting Review 86, 1851-1885.

Armstrong, C.S., Balakrishnan, K., Cohen, D., 2012. Corporate governance and the information environment: evidence from state antitakeover laws. Journal of Accounting and Economics 53, 185-204.

Balakrishnan, K., Billings, M.B., Kelly, B.T., Ljungqvist, A., 2012. Shaping liquidity: on the causal effects of voluntary disclosure. Unpublished working paper. University of Pennsylvania, New York University, University of Chicago.

Barton, J., Simko, P., 2002. The balance sheet as an earnings management constraint. Accounting Review 77, 1-27.

Bebchuk, L., Cohen, A., Ferrell, A., 2009. What matters in corporate governance? Review of Financial Studies 22, 783-827.

Bergstresser, D., Philippon, T., 2006. CEO incentives and earnings management. Journal of Financial Economics 80, 511-529.

Bradshaw, M.T., Richardson, S.A., Sloan, R.G., 2006. The relation between corporate financing activities, analysts' forecasts and stock returns. Journal of Accounting and Economics 42, 53-85.

Brickley, J.A., Coles, J.L., Jarrell, G., 1997. Leadership structure: separating the CEO and chairman of the board. Journal of Corporate Finance 3, 189-220.

Collins-Thompson, K., Callan, J., 2005. Predicting reading difficulty with statistical language models. Journal of the American Society for Information Science and Technology 56, 1448-1462.

Dechow, P.M., Sloan, R.G., Sweeney, A.P., 1995. Detecting earnings management. Accounting Review 70, 193-225.
Derrien, F., Kecskes, A. The real effects of financial shocks: evidence from exogenous changes in analyst coverage. Journal of Finance, forthcoming.

Derrien, F., Kecskes, A., Mansi, S., 2012. Information asymmetry, the cost of debt, and credit events. Unpublished working paper. HEC Paris and Virginia Polytechnic Institute.

Diamond, D.W., 1985. Optimal release of information by firms. Journal of Finance 40, 1071-1094.

Diamond, D.W., Verrecchia, R.E., 1991. Disclosure, liquidity, and the cost of capital. Journal of Finance 46, 1325-1359.

Dyck, A., Morse, A., Zingales, L., 2010. Who blows the whistle on corporate fraud? Journal of Finance 65, 2213-2253.

Easley, D., Kiefer, N., O’Hara, M., 1996. Cream-skimming or profitsharing? The curious role of purchased order flow. Journal of Finance 51, 811-833.

Fama, E.F., French, K.R., 2008. Dissecting anomalies. Journal of Finance 63, 1653-1678.

Fong, K.Y.L., Hong, H.G., Kacperczyk, M.T., Kubik, J.D., 2012. Do security analysts discipline credit rating agencies? Unpublished working paper. University of New South Wales, Princeton University, New York University, Syracuse University.

Gompers, P., Ishii, J., Metrick, A., 2003. Corporate governance and equity prices. Quarterly Journal of Economics 118, 107-156.

Gompers, P.A., Ishii, J., Metrick, A., 2010. Extreme governance: an analysis of dual-class firms in the United States. Review of Financial Studies 23, 1051-1088.

He, J., Tian, X. The dark side of analyst coverage: the case of innovation. Journal of Financial Economics, forthcoming.

Healy, P.M., Hutton, A.P., Palepu, K.G., 1999. Stock performance and intermediation changes surrounding sustained increases in disclosure. Contemporary Accounting Research 16, 485-520.

Hong, H., Kacperczyk, M., 2010. Competition and bias. Quarterly Journal of Economics 125, 1683-1725.

Hribar, P., Collins, D.W., 2002. Errors in estimating accruals: implications for empirical research. Journal of Accounting Research 40, 105-134

Jensen, M.C., 1993. The modern industrial revolution, exit, and the failure of internal control systems. Journal of Finance 48, 831-880.

Jones, J.J., 1991. Earnings management during import relief investigations. Journal of Accounting Research 29, 193-228.

Karpoff, J.M., Lee, D.S., Martin, G.S., 2008a. The consequences to managers for financial misrepresentation. Journal of Financial Economics $88,193-215$.

Karpoff, J.M., Lee, D.S., Martin, G.S., 2008b. The cost to firms of cooking the books. Journal of Financial and Quantitative Analysis 43, 581-611.

Kedia, S., Philippon, T., 2009. The economics of fraudulent accounting. Review of Financial Studies 22, 2169-2199.

Kelly, B.T., Ljungqvist, A., 2007. The value of research. Unpublished working paper. University of Chicago, New York University.

Kelly, B.T., Ljungqvist, A., 2012. Testing asymmetric-information asset pricing models. Review of Financial Studies 25, 1366-1413.

Lang, M.H., Lundholm, R.J., 1993. Cross-sectional determinants of analyst ratings of corporate disclosures. Journal of Accounting Research 31, 246-271.

Lang, M.H., Lundholm, R.J., 2000. Voluntary disclosure and equity offerings: reducing information asymmetry or hyping the stock? Contemporary Accounting Research 17, 623-662.

Li, F., 2008. Annual report readability, current earnings, and earnings persistence. Journal of Accounting and Economics 45, 221-247.

Myers, S.C., Majluf, N.S., 1984. Corporate financing and investment decisions when firms have information that investors do not have. Journal of Financial Economics 13, 187-221.

Richardson, S., Sloan, R., Soliman, M., Tuna, I., 2005. Accrual reliability, earnings persistence and stock prices. Journal of Accounting and Economics 39, 437-485.

Roberts, M.R., Whited, T. Endogeneity in empirical corporate finance. In: Constantinides, G., Harris, M., Stulz, R. (Eds), Handbook of the Economics of Finance, vol. 2. Elsevier Science, North Holland, http://dx.doi.org/10.1016/B978-0-44-453594-8.00007-0, in press.

Rosenbaum, P., Rubin, D., 1983. The central role of the propensity score in observational studies for causal effects. Biometrika 70, 41-55.

Sloan, R., 1996. Do stock prices reflect information in accruals and cash flows about future earnings? Accounting Review 71, 289-315.

$\mathrm{Yu}, \mathrm{F} ., 2008$. Analyst coverage and earnings management. Journal of Financial Economics 88, 245-271. 